\title{
REVIEW
}

\section{Risk determination and prevention of breast cancer}

\author{
Anthony Howell ${ }^{1,2,3^{*}}$, Annie S Anderson ${ }^{4}$, Robert B Clarke ${ }^{3}$, Stephen W Duffy ${ }^{5}$, D Gareth Evans ${ }^{1,2,6}$, \\ Montserat Garcia-Closas ${ }^{7}$, Andy J Gescher ${ }^{8}$, Timothy J Key ${ }^{9}$, John M Saxton ${ }^{10}$ and Michelle N Harvie ${ }^{1,2}$
}

\begin{abstract}
Breast cancer is an increasing public health problem. Substantial advances have been made in the treatment of breast cancer, but the introduction of methods to predict women at elevated risk and prevent the disease has been less successful. Here, we summarize recent data on newer approaches to risk prediction, available approaches to prevention, how new approaches may be made, and the difficult problem of using what we already know to prevent breast cancer in populations. During 2012, the Breast Cancer Campaign facilitated a series of workshops, each covering a specialty area of breast cancer to identify gaps in our knowledge. The risk-and-prevention panel involved in this exercise was asked to expand and update its report and review recent relevant peer-reviewed literature. The enlarged position paper presented here highlights the key gaps in risk-and-prevention research that were identified, together with recommendations for action. The panel estimated from the relevant literature that potentially $50 \%$ of breast cancer could be prevented in the subgroup of women at high and moderate risk of breast cancer by using current chemoprevention (tamoxifen, raloxifene, exemestane, and anastrozole) and that, in all women, lifestyle measures, including weight control, exercise, and moderating alcohol intake, could reduce breast cancer risk by about 30\%. Risk may be estimated by standard models potentially with the addition of, for example, mammographic density and appropriate single-nucleotide polymorphisms. This review expands on four areas: (a) the prediction of breast cancer risk, (b) the evidence for the effectiveness of preventive therapy and lifestyle approaches to prevention, (c) how understanding the biology of the breast may lead to new targets for prevention, and (d) a summary of published guidelines for preventive approaches and measures required for their implementation. We hope that efforts to fill these and other gaps will lead to considerable advances in our efforts to predict risk and prevent breast cancer over the next 10 years.
\end{abstract}

\section{Introduction}

Breast cancer remains a major public health problem. The incidence is rising in most countries and is projected to rise further over the next 20 years despite current efforts to prevent the disease [1-4]. The increased incidence is not surprising since there has been, in most countries, an increase in numbers of women with major breast cancer risk factors, including lower age of menarche, late age of first pregnancy, fewer pregnancies, shorter or no periods of breastfeeding, and a later menopause. Other risk factors which add to the burden of breast cancer are the increase

\footnotetext{
* Correspondence: tony.howell@ics.manchester.ac.uk

${ }^{1}$ Genesis Breast Cancer Prevention Centre, University Hospital of South Manchester, Southmoor Road, Wythenshawe, Manchester M29 9LT, UK ${ }^{2}$ The Christie, NHS Foundation Trust, Wilmslow Road, Manchester M20 2QJ, UK Full list of author information is available at the end of the article
}

in obesity, alcohol consumption, inactivity, and hormone replacement therapy (HRT) [4]. The impact of hereditary breast cancer has also increased. For example, it is estimated that the penetrance of the breast cancer 2 (BRCA2) founder mutation in Iceland increased fourfold over the last century, and the cumulative incidence of sporadic breast cancer by age 70 also increased fourfold, from $2.5 \%$ to $11 \%$ of the population, over the same period [5]. Birth cohort effects have also been seen for both $B R C A 1$ and $B R C A 2$ in other countries [6,7]. These data suggest that both familial and non-familial risks have increased. The Collaborative Group on Hormonal Factors in Breast Cancer (2002) estimated that the cumulative incidence of breast cancer in developed countries would be reduced by more than half, from 6.3 to 2.7 per 100 women, by age 70 if women had on average more children and breastfed for 
longer periods as seen in some developing countries [8]. Given global increases in population growth and the strong evidence that a woman's ability to control her fertility may improve her social, economic, and overall health, it is not considered desirable to increase the birth rate per woman or to encourage pregnancies at a very young age. However, breastfeeding can and should be encouraged for many reasons, including possibly for the reduction of breast cancer risk. Many of the risks of reproductive factors are related to the effects of estrogen as demonstrated by the reduction in breast cancer incidence after an early oophorectomy, by inhibition of the estrogen receptor (ER) by using selective estrogen receptor modulators (SERMs) such as a tamoxifen or raloxifene [9], or by blocking estrogen synthesis by using aromatase inhibitors (AIs) such as exemestane [10] and anastrozole [11,12].

A paradigm for preventative therapy (chemoprevention) is cardiovascular disease (CVD). The introduction of drugs that suppress cholesterol synthesis, modify platelet aggregation, or lower blood pressure has led to a steady decline in CVD over the past three decades, such that deaths from CVD in women less than 85 years old fell below those for cancer in 1999 [13]. The cardiovascular community is helped by the reduction of a major risk factor (smoking) and having easy-to-measure, repeatable biomarkers (cholesterol and blood pressure). CVD deaths are also reduced by optimal treatment of disease once it arises; this is also true for breast cancer treatment, in which (as a result of the introduction of screening and optimizing treatments) deaths have decreased by approximately one third over the past 20 years. This is a major advance for breast cancer; however, primary prevention has not occurred at the population level in contradistinction to CVD.

The fraction of breast cancer cases attributable to lifestyle and environmental factors in the UK was estimated to be $26.8 \%$ in 2010 [14], and a recent review suggests that half of breast cancer cases may be prevented if chemoprevention is applied in appropriate at-risk populations and the major modifiable risk factors, including achieving and maintaining a healthy weight, regular physical activity (PA), and minimal alcohol intake, are instituted [4]. Thus, there are further possibilities of important reductions in breast cancer incidence. However, major gaps exist in our knowledge to determine the risk of breast cancer accurately in order to apply these approaches to appropriate populations of women.

This review is an expansion and update of a brief review published in the Gap Analysis in 2013 of breast cancer research overall [1]. Besides summarizing new data published over the past year, this review has enabled us to give more comprehensive summaries of risk factors, approaches to prevention, and how understanding the biology of the breast may lead to new approaches to risk and prevention and also to expand on the all-important area of how to implement current risk prediction and preventive measures in the population (Table 1).

\section{Methods of risk assessment}

Models and scoring systems have been developed either to predict the probability that a person carries a mutation in the $B R C A 1 / 2$ genes, which is relevant to relatively small numbers of women with strong family histories, or to predict breast cancer risk over time $[15,16]$. Computer models such as BOADICEA (The Breast and Ovarian Analysis of Disease Incidence and Carrier Estimation Algorithm) and BRCAPRO (risk estimator for breast and ovarian cancer) [17] and scoring systems perform well for predicting BRCA1/2 mutation carrier probability, which is important in deciding whether to perform a genetic test $[18,19]$.

Of relevance to all women, several models have been developed to predict risk of breast cancer over time (for example, 5-year, 10-year, or lifetime risks). These predict the probability that a woman in the population with a particular combination of risk factors will develop breast cancer [14-16]. The tested models include the TyrerCuzick [20] and Gail [21] models, both of which include family history and non-familial risk factors, BOADICEA [22], a modification of the Claus model to include nonfamilial risk factors [23], the Rosner-Colditz model [24],

\section{Table 1 Major gaps in our knowledge concerning risk assessment and prevention of breast cancer}

A. Gaps in risk estimation

A1. The best standard model to estimate risk in the general population and in women at high risk

A2. What additional factors will give maximal improvement in a model?

A3. Prediction of risk in the proportion of women with none of the current risk factors

B. Gaps in preventive therapy and lifestyle prevention

B1. Prediction of women who will benefit from current preventive therapy

B2. New agents for women who will not benefit from current preventive therapy

B3. Optimal measures for weight control and exercise: timings of this in the life course, who to target, and type of interventions

C. Gaps in understanding the biology of breast cancer risk

C1. Mechanisms of the effects of pregnancy on risk

C2. Mechanism of the lack of involution in some breasts with menopause?

C3. Mechanism of energy restriction on reduction of risk

D. Gaps in implementing known preventive measures

D1. Determination of the approximately $10 \%$ of women at high and moderate risk in populations

D2. How to make preventive therapy available to the subset of women who will benefit

D3. Optimal weight control and exercise programs for women at any age and in all countries and how we engage individuals in cancer prevention throughout the life course 
and several others, many of which require further validation [16].

The Gail model includes these risk factors: age at menarche, age at first live birth, number of previous breast biopsies, benign breast disease, and number of firstdegree relatives with breast cancer. Studies indicate that the Gail model is well calibrated in regularly screened American women [25] and when using updated breast cancer incidence [26]. However, recent studies in the UK and US suggest that it may under-predict actual risk relative to the Tyrer-Cuzick model [27-29], possibly because of the limited family history and not including age of onset of cancer in the family whereas the Tyrer-Cuzick model also includes second-degree family history, age of onset of cancer, and use of HRT.

Although current models can give an accurate estimation of lifetime risk (for example, we can tell a woman, with some accuracy, that she has a 1 in 3 lifetime risk of breast cancer), we cannot tell her whether she is the one who will develop the disease or whether she is one of the two women who will not. To fill this gap in our knowledge, there is great interest in adding other risk factors to current models, such as mammographic density [30,31], singlenucleotide polymorphisms (SNPs) [32,33], estimation of hormone levels [34], and lifestyle factors in order to test whether they improve the accuracy of risk prediction in the female population. Here, we examine recent progress made in improving available breast cancer risk prediction models.

\section{Improving risk estimation - mammographic density}

The available data on mammographic density in relation to breast cancer risk have been reviewed recently [30,31]. Dense tissue on the mammogram is white, whereas fat tissue is radio-lucent and appears black. An overview of 42 studies of visually assessed mammographic density (the proportion of the breast as a percentage which appears white) indicated that the relative risk of breast cancer for women with $70 \%$ or more density was 4.64 -fold greater compared with women with less than $5 \%$ density [35]. In this report, the magnitude of the risk was greater using percentage density than for other visual methods of density estimation, such as Wolffe patterns or the Breast Imaging Reporting and Data System (BI-RADS) classification, which divides density into four visually assessed categories and is widely used in the US. The distribution of visually assessed mammographic density is shown in Figure 1.

Four studies have already assessed whether adding a measure of mammographic density improves risk estimation

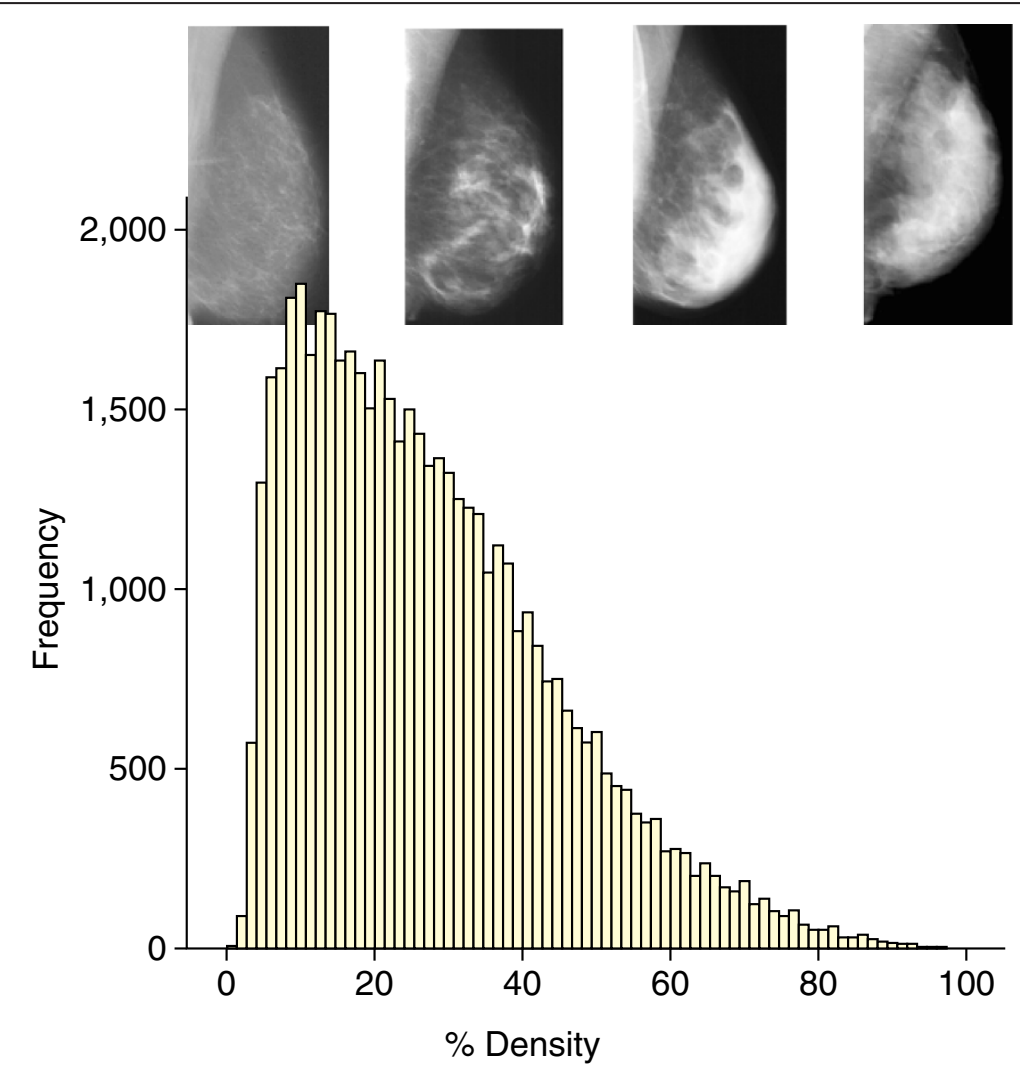

Figure 1 An example of the distribution of visually assessed percentage density of the breast. The sample consists of 50,831 women between 46 and 73 years of age. Density was estimated in two views of each breast on a visual analogue scale, and the four readings were combined to give a single value per woman [54]. 
compared with the estimation using standard models alone. A standard measure of improvement of risk assessment is the C-statistic. This is the area under the receiver operating curve (AUC), which in turn is a reflection of the sensitivity and specificity of the model. The higher the C-statistic (AUC), the greater the discriminatory accuracy of the model. An AUC of 0.5 identifies a model whose discriminatory accuracy is no better than chance alone, whereas an AUC of 1.0 identifies a model with perfect discriminatory accuracy. In practice, AUCs of 0.7 or 0.8 are consistent with good discriminatory accuracy [15].

Tice and colleagues [36] estimated adding the BI-RADS assessed density to the Gail model. The C-statistic for the Gail model in this study was 0.67 , but adding density to the model modestly increased the C-statistic to 0.68 , although this small increase in discriminatory accuracy was significant $(P<0.01)$. Barlow and colleagues [37] reported an increase of the C-statistic from 0.605 (95\% confidence interval (CI) 0.60 to 0.61 ) to 0.62 (95\% C1 0.62 to 0.63 ) also by adding BI-RADS density to the Gail model. Chen and colleagues [38] demonstrated that adding percentage density to the Gail Model 2 significantly $(P=0.015)$ increased the C-statistic, from 0.602 to 0.664 . Tice and colleagues [39] performed a second study of adding BI-RADS to a modification of the Gail model and reported a C-statistic rise from 0.61 to 0.66 . These studies are important in that there was an improvement, albeit modest, in discriminatory accuracy in all of them.

It should be borne in mind that owing to the correlations among breast cancer risk factors, the addition of a new risk factor, however powerful, to a model already containing several risk factors will invariably make a modest difference to prediction measures such as AUC. Whereas some studies have suggested that density adds little to risk prediction [40], some find AUCs for density or another breast composition measure alone of 0.6 to 0.8 [41-44], which is similar to those observed for the Gail and other models.

Although the improvement in the C-statistic shown in these studies is modest, a more relevant measure of the utility of adding density information to risk models is how much it improves the ability to identify women at different levels of absolute risk for breast cancer (for example, reclassification of women crossing threshold risk levels set for public health interventions such as enhanced screening or chemoprevention). Further validation of risk models, including BI-RADS or other density measures such as volumetric approaches in prospective cohort studies, is needed to assess potential value of density in risk-stratified prevention or screening programs.

One method of density estimation, the interactive thresholding technique known as CUMULUS developed in Toronto [45], determines the area of dense and nondense tissue, unlike visual techniques outlined above, and is widely regarded as a gold standard method for estimation of density. A meta-analysis of 13 case-control studies using this technique indicated that the association of density with risk was strong. Perhaps surprisingly, the risk prediction was better for dense area as a percentage of the whole breast rather than absolute dense area [46]. There remains a need to assess whether some measure of CUMULUS density adds to the predictive accuracy of standard models. CUMULUS is timeconsuming and requires specialized training, and the technique will require greater automation to be useful on a population basis (Nickson and colleagues [47]).

Methods are being developed to assess the volume of dense and non-dense tissue in the breast and may be more relevant not only because density is a volume but because they can be partially or fully automated with the potential for use in populations of women. The first reported estimation of the relationship of volumetric density to standard risk factors was by Shepherd and colleagues [48], who used a technique called single $\mathrm{x}$-ray absorptiometry. In their study, the C-statistic for risk factors alone was 0.609, which significantly increased to 0.667 when log fibroglandular volume was added to standard risk factors. The study was performed by using analogue mammograms. Newer automatic techniques - such as Quantra (Hologic, Inc., Bedford, MA, USA) and Volpara (Matakina International, Wellington, New Zealand) - are designed for use with modern digital mammograms and are fully automatic. How they add to standard models is being tested, but studies already demonstrate that they are consistent with magnetic resonance imaging measures of volumetric density $[49,50]$.

\section{Improving risk estimation - single-nucleotide polymorphisms}

Mutations in high-risk breast cancer genes such as $B R C A 1 / 2$ affect only small numbers of women, whereas variation in lower-impact, common susceptibly loci or SNPs can be responsible for a larger percentage of cancers in the population. Although it has been predicted for some time that risk would be related to polygenic inheritance of common low-penetrance loci [51], these have only recently been identified. SNPs are, by definition, common alterations in the DNA code that are mostly thought to be non-functional variants that frequently occur outside functional genes. Relative risks from SNPs are small (maximum risk is around 1.43-fold) and many have effects of less than 1.1-fold. Recent reports of 'risk' SNPs are a result of large-scale multinational collaborations involving tens of thousands of breast cancer cases and appropriate controls. Such large-scale studies are required since each SNP is associated with a small increase or decrease in risk. However, in combination (for example, through polygenic risk scores based on the average of the number of risk 
alleles weighted by the relative risk associated with each allele), combined SNPs can be associated with substantial increases or decreases in risk. The number of validated SNPs associated with breast cancer risk is currently over 70 , but it is thought that there may be hundreds more that affect breast cancer risk [32].

Based on the first few SNPs identified, studies were performed to determine how they might add to the Gail model. All studies showed some improvement in the C-statistic when SNP scores and the Gail model were combined. Mealiffe and colleagues [52] using seven SNPs reported an increase in AUC from 0.58 to $0.61(P=0.001)$, Wacholder and colleagues [53] using 10 SNPs reported an increase in the AUC from 0.58 to $0.62(P<0.001)$, and Gail [54] predicted an increase in the C-statistic from 0.61 to 0.63. More recently, Dite and colleagues [55] included seven SNPs and reported an increase in AUC from 0.58 to $0.61(P<0.001)$.

An additional way to determine the value of adding SNPs to risk models is to assess changes in risk group stratification before and after adding SNPs. For instance, increasing the numbers of women estimated to be truly at high or low risk would be of value clinically. All the studies outlined above resulted in changes in classification to higher and lower risk categories resulting in a 'widening' of the risk distribution curves. For example, in the study by Comen and colleagues [56], a combination of 10 risk SNPs and the Gail model resulted in $20 \%$ of women being re-classified into a lower and $20 \%$ into a higher risk group as defined by quintiles. More recently, Brentnall and colleagues [57] and Evans and colleagues [58] estimated the effect on risk of combining 18 or 67 SNPs and the Tyrer-Cuzick model (Figure 2). Adding more SNPs changed the risk distribution so that more women were in the high- and low-risk groups, respectively (Figure 2).

The studies outlined above highlight the prospects of using SNPs for improved risk prediction in high-risk clinics and in the general population. Further improvements may come from introducing more SNPs and the prospects of being able to predict the risk of specific breast cancer subtypes, such as $\mathrm{ER}^{+}$[59], $\mathrm{ER}^{-}$[60], grade III [61], and triple-negative [62] tumors, separately, knowledge of which could direct preventative approaches [63].

\section{Improving risk estimation - hormone measurements}

Large studies with long-term follow-up indicate that many hormones and growth factors are associated with an increased risk of breast cancer. The important question is whether any of them could be incorporated into models of breast cancer risk prediction. The Endogenous Hormones and Breast Cancer Collaborative Group reported that risk

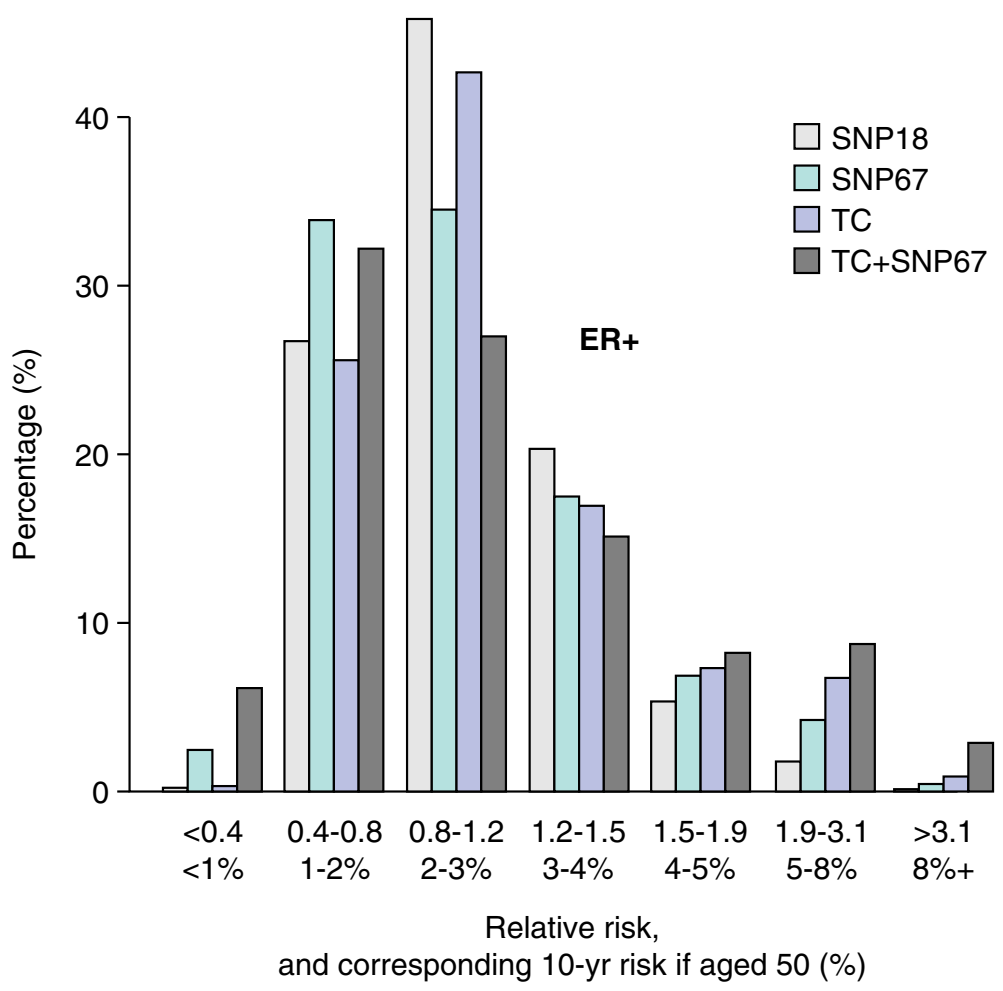

Figure 2 Estimation of the effect on the distribution of Tyrer-Cuzick scores by adding the results of 18 or 67 single-nucleotide polymorphisms (SNPs) in 10,000 women [53]. Adding SNPs increases the number of women in high- and low-risk groups. ER, estrogen receptor; SNP 18 and SNP 67, distribution using SNPs alone; TC, the Tyrer-Cuzick score alone; TC + SNP67, distribution of the combined score. 
of breast cancer was related to steroid hormones such as estradiol, testosterone, and sex hormone-binding globulin in pre- and post-menopausal women and was recently confirmed in the European Prospective Investigation into Cancer study [64-67]. The relation of body mass index (BMI) with risk is attenuated by adjusting for estrogen, but the relation of estrogen with risk is not attenuated by adjusting for BMI. This is what would be expected if estrogen mediates the effect of BMI [64]. Thus, estrogens may explain the increased risk of breast cancer in obese post-menopausal women, although this does not preclude other hormones and cytokines from mediating the effects of estrogen (which may be more readily measurable) or other mechanisms by which overweight and obesity might affect risk $[64,68]$.

The use of hormone measurements in breast cancer to incorporate into risk models is attractive. However, measurement, particularly in post-menopausal women, is problematic because of assay variation related to low hormone levels and other unknown causes of variation in hormone levels over time [69]. Nevertheless, Jones and colleagues [70] demonstrated that change in estradiol and testosterone may be good biomarkers of the effectiveness of weight loss and this is supported by recent data from the Nurses' Health Study [71]. Other growth factors/ hormones such as insulin-like growth factor-1 (IGF-1) and prolactin are associated with breast cancer risk, particularly in post-menopausal women, and may possibly be useful in models, although the risk increases between high and lower risk groups of hormone concentrations are relatively small [72-75].

\section{Improving risk estimation - other methods}

New biomarkers for risk prediction are likely to come from measures in blood or tissues by a variety of techniques. At present, it appears that none of these is ready for incorporation into the standard models, but given the pace of advance they are likely to be in the near future. Examples of some current approaches include the development of assays for serum antibodies against epithelial antigens [76], gene expression in peripheral blood white cells [77], blood epigenetic markers [78], and developments in high-throughput proteomics [79] and adductomics [80]. Incorporating new risk markers into risk models may not be straightforward since extensive validation will be required and potential interactions with known existing factors will need to be carefully evaluated.

\section{Breast cancer prevention}

What can we advise women to do with respect to prevention? Recent reviews focus on various aspects of prevention, including SERMs and AIs for the chemoprevention of $\mathrm{ER}^{+}$cancers $[81,82]$, chemoprevention for $\mathrm{ER}^{-}$cancers
$[83,84]$, and lifestyle changes $[4,85,86]$. These reviews are helpful in pointing out some areas that are potentially clinically useful and others where far more investigational work is required.

There is probably sufficient evidence from the randomized trials for the use of SERMs and AIs for use in women at high and moderate breast cancer risk $[9,11]$ and sufficient observational data to advise weight control, exercise, and moderation of alcohol intake $[4,86]$. In this section, we review the data which support these suppositions for each of the approaches to prevention; in the next section, we review possible new investigational avenues.

\section{Preventative therapy (chemoprevention)}

There have been nine randomized trials of SERMs [9] and two trials of AIs $[10,11]$ mainly in women at increased risk of breast cancer but also in women with osteoporosis or heart disease (raloxifene). In the SERM trials, 83,399 participants were included with 306,617 years of follow-up over an average period of 65 months. The overall reduction in all breast cancer (including ductal carcinoma in situ) using tamoxifen $20 \mathrm{mg}$ per day was $38 \%(P<0.0001)$ [9] with an estimated 10-year reduction in cumulative incidence from $6.3 \%$ in the control group to $4.2 \%$ in the SERM groups. This overview included the SERMs lasofoxifene and arzoxifene, which are not undergoing further development by their respective drug companies. This leaves tamoxifen and raloxifene as the two SERMs in clinical practice. These were compared in a randomized trial (the Study of Tamoxifen and Raloxifene, or STAR, trial) [87]. Tamoxifen was significantly superior to raloxifene in longer-term follow-up for preventing invasive breast cancer (relative risk raloxifene/tamoxifen 1.24, 95\% CI 1.05 to 1.47). Nonetheless, raloxifene was associated with fewer side effects than tamoxifen, particularly with respect to the uterus, and may be preferable in post-menopausal women.

When given after surgery to prevent relapse of breast cancer, AIs are generally superior to tamoxifen. This led to the initiation of two placebo-controlled trials in postmenopausal women at increased breast cancer risk. One tested the AI exemestane and reported a reduction of breast cancer risk of $65 \%$ after 5 years of treatment [10]. In the other trial (International Breast Cancer Intervention Study II, or IBIS II), anastrozole was compared with placebo [11]. In that study, 3,864 post-menopausal women between 40 and 70 years of age at increased risk of breast cancer were randomly assigned to anastrozole $1 \mathrm{mg}$ per day or placebo for 5 years. A recent report indicates that the incidence of breast cancer was reduced by $53 \%$ (hazard ratio $0.47,95 \%$ CI 0.32 to 0.68 ) by use of anastrozole. Compared with SERMs, AIs are not associated with an increased risk of thromboembolic disease 
and uterine problems, including cancer, but are associated with increased mild to moderate bone/muscle pain and reduced bone density.

Additional hormonal approaches to prevention surround the use of HRT. Results from the Women's Health Initiative (WHI) randomized controlled trial of premarin and medroxyprogesterone acetate indicate that the combination given after menopause increases breast cancer risk [88], a result supported by many observational studies. After the publication of the WHI study, many women stopped HRT and it has been suggested by some to have been associated with a reduction in the incidence of breast cancer, CVD, and venous thrombosis as well as potential considerable savings in health resources [89]. However, the magnitude of these associations, as well as the question of whether a cause-and-effect relationship exists, remains controversial. In contrast, estrogen-only HRT using premarin resulted in a reduction of the incidence and deaths from breast cancer in the second WHI trial performed in women with a previous hysterectomy [90]. This result is supported by some, but not all, observational studies and indicates that premarin may be regarded as a breast cancer preventive agent [91].

\section{Lifestyle}

The World Cancer Research Fund/American Institute for Cancer Research (WCRF/AICR) has estimated that over $40 \%$ of post-menopausal breast cancer could be prevented by reductions in alcohol, excess body weight, and inactivity [92]. These estimates differ from those suggested by others as outlined above $[4,14]$, but all of the estimates point in the same direction and indicate the importance of lifestyle throughout the lifespan and the challenge of finding ways to support women to achieve healthy ways of life.

\section{Energy restriction/weight control}

Strong observational data indicate that weight gain in the premenopausal period and being overweight or obese after menopause increase breast cancer risk $[4,93]$. In a metaanalysis, Renehan and colleagues [93] estimated that for each $5 \mathrm{~kg} / \mathrm{m}^{2}$ increase in BMI the risk of breast cancer was increased by $12 \%$. Evidence from two large observational studies indicates that pre- or post-menopausal weight loss reduces the risk of post-menopausal breast cancer. In the Iowa Women's Health Study, sustained weight reduction of $5 \%$ of body weight reduced postmenopausal breast cancer risk by $25 \%$ to $40 \%$ compared with women who continued to gain weight [94]. In the Nurses' Health Study, post-menopausal women who did not take HRT and maintained a body weight reduction of $10 \mathrm{~kg}$ or more had a $50 \%$ reduction in the risk of breast cancer [95]. There is some evidence from the National Surgical Adjuvant Breast Project P-I and STAR SERM trials that weight reduction after the age of 35 is also effective [96]. It is important to emphasize the other wellknown beneficial effects of weight control, including the reduction of diabetes $[97,98]$ and CVD $[99,100]$. Modest weight loss of $5 \%$ to $10 \%$ will reduce the risk of diabetes by up to $60 \%$ and can reduce low-density lipoprotein cholesterol by $15 \%$ and triglycerides by $20 \%$ to $30 \%$, increase high-density lipoprotein cholesterol by $8 \%$ to $10 \%$, and reduce blood pressure by around 5\%. These changes in CVD risk markers suggest a $30 \%$ or greater reduction in risk of CVD.

\section{Dietary components and prevention}

There is great interest in determining whether components of diets such as saturated fat content or the amount of fruit and vegetables is related to the risk of breast cancer. A randomized trial performed by the WHI of reduction of the proportion of fat in the diet resulted in a non-significant $8 \%$ reduction in the risk of breast cancer, but there was some confounding with weight loss [101]. After surgery for breast cancer, where dietary interventions were performed in addition to standard adjuvant therapy, reduction of fat was associated with a $23 \%$ reduction in recurrence. This study was also confounded by weight loss in the intervention arm and thus in both studies the reason for the effects on risks is not clear [102]. There was no advantage to an increase of fruit and vegetable intake in another large randomized adjuvant trial [103]. Recent large pooled analyses have suggested that both dietary intake of vegetables and circulating concentrations of some carotenoids may be inversely associated with the risk for $\mathrm{ER}^{-}$breast cancer but not with the risk for $\mathrm{ER}^{+}$disease. This topic requires further investigation $[104,105]$. Whereas intervention studies give little support for the preventive efficacy of specific dietary components, prospective cohort studies provide indications that adherence to dietary guidelines and certain types of diet may impact on breast cancer risk. Adherence to dietary and lifestyle guidelines appears to be beneficial. In a study from Canada [106], adherence to the American Cancer Society (ACS) and WCRF/AICR dietary/lifestyle guidelines appeared to be beneficial: 49,613 women completed dietary and lifestyle questionnaires, and adherence was associated with a $31 \%$ reduction of breast cancer estimated over 16 years compared with women who did not follow the guidelines. The guidelines include advice on weight control, PA, alcohol intake, and intake of red meat, vegetables, fruit, and sodium. In another study, the WHI reported the effects of adherence to ACS guidelines in 65,838 post-menopausal women and indicated that adherence to guidelines reduced breast cancer risk by $22 \%$ after 12.6 years of follow-up [107].

Adherence to dietary types may also affect risk. For example, in the California Teachers Study, data from 91,779 women were analyzed according to predominant dietary 
pattern by using principal component factor analysis [108]. A greater consumption of plant-based foods was associated with a $15 \%$ reduction in breast cancer risk (85\% CI 0.76 to 0.95 ). A systematic review of dietary patterns and breast cancer was performed by Albuquerque and colleagues [109], who concluded that a Mediterranean dietary pattern and diets composed largely of vegetables, fruit, fish, and soy are associated with a decreased risk of breast cancer. Risk reduction may also be helped by appropriate intakes of dietary fiber, fruit, and vegetables [110-114].

\section{Physical activity}

More than half of the US population does not meet the recommended PA guidelines. In addition, the most recent Health Survey for England [115] showed that over $40 \%$ of adult women (at least 19 years old) are not meeting current guidelines of 150 minutes of moderate or 75 minutes of vigorous PA per week [116]. The WCRF/ AICR Expert Report [117] described the evidence for an inverse association between PA and breast cancer risk as 'probable' and 'limited - suggestive' for post- and premenopausal women, respectively. A more recent review of 73 observational studies indicated that moderate to vigorous PA reduces breast cancer risk by an average of $25 \%$ in pre- and post-menopausal women compared with inactive women [118]. The strongest inverse associations with breast cancer risk were observed for recreational PA, lifetime PA, post-menopausal PA, and participation in moderate to vigorous PA. There was also evidence of dose-response relationships, with higher volumes of PA associated with greater risk reduction, but with the most pronounced reductions in risk being observed in lean versus obese women. The optimal level of PA for breast cancer risk reduction is unclear, however, and may be greater than current recommendations [118]. A major limitation of observational studies is the heterogeneity of self-report questionnaires that have been used to measure PA. The use of more objective measures, such as 7-day accelerometry, would provide more robust PA data. There is a clear need for randomized controlled trials which include clinical end-points or biomarkers on the causal pathway, but designing such trials is challenging because of the large sample size required and the expense of collecting longterm follow-up data.

\section{Alcohol}

It is estimated that breast cancer risk is increased by $7 \%$ to $10 \%$ for each one-unit increase in intake of alcohol per day (a unit is half a pint of $4 \%$ strength beer or cider or $25 \mathrm{~mL}$ of $40 \%$ strength spirits, and a small $125-\mathrm{mL}$ glass of $12 \%$ strength wine is 1.5 units). In the Nurses' Health Study, women who consumed 4 to 9 units per week were $15 \%$ more likely to develop breast cancer compared with never drinkers [119]. Women with the highest alcohol intake (of at least 27 units per week) were $51 \%$ more likely to develop breast cancer compared with non-drinkers. These studies suggest that women who want to minimize their breast cancer risk should not be drinking more than one unit daily and probably have at least two alcohol-free days weekly. Studies show that the negative effect of alcohol may be abrogated by adequate dietary folate intake (rather than supplements) and should be pointed out as a preventive measure for women who find reduction in alcohol intake difficult [120]. Better life expectancy associated with moderate alcohol intake compared with none in a large meta-analysis should be balanced against recommending zero intake [121].

It is important to be aware that lifestyle prevention includes not only middle- and late-age women but younger women after menarche. Animal experiments and modeling of the reproductive events in women indicate that the most susceptible period for carcinogenesis is during the period between menarche and first pregnancy $[122,123]$. In women, this susceptibility is highlighted by the increase in premalignant lesions in the breast of women who drank alcohol or smoked (or both) during this period of early life [124].

\section{The biology of risk and prevention as an indicator of potential new approaches}

One way to develop new approaches to prevention is to assume that understanding the biological basis of breast development will give indications of potential targets for therapeutic interventions. Great insights into the mechanisms of breast development in utero and at puberty, particularly in the rodent mammary gland, have been discovered and are summarized in recent reviews $[125,126]$. They highlight the crucial importance of epithelial-stromal interactions for normal breast development and of the individual cell types within the stroma, including immune cells, fibroblasts, or adipocytes. Importantly, it has been shown that experimental inhibition of any one of these interactions results in lack of breast development and this has implications for our thinking about approaches to prevention (Figure 3).

The experiments outlined above cannot be performed in humans. However, another approach to the development of prevention is understanding the biological mechanisms of risk factors for breast cancer. Here, we discuss some examples which support this view with respect to estrogen and the breast, early and late first pregnancy, menopausal involution of epithelial cells, mammographic density, and mechanism of the effects of energy restriction and exercise.

\section{Estrogen and the breast}

The most successful preventative approach to breast cancer to date, reducing the effects of estrogen on the breast, 


\section{(a)}
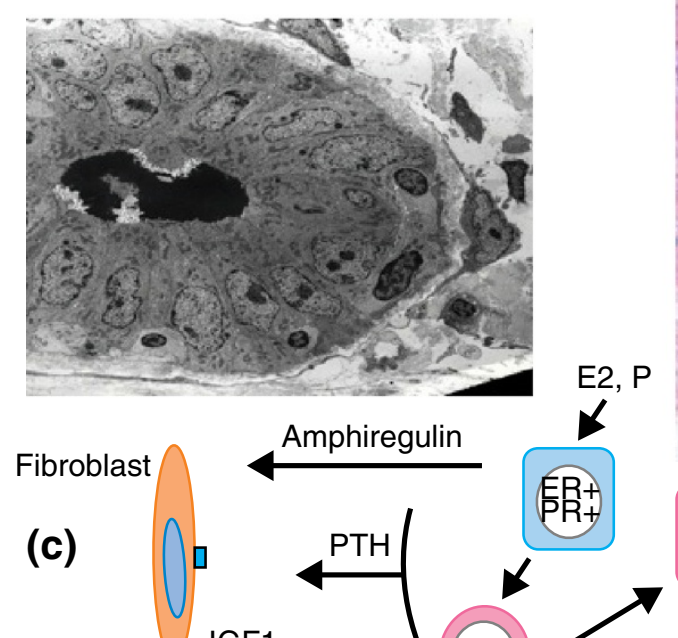

(c)

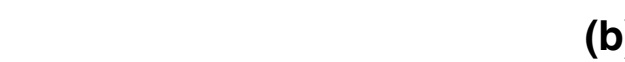

\section{(b)}

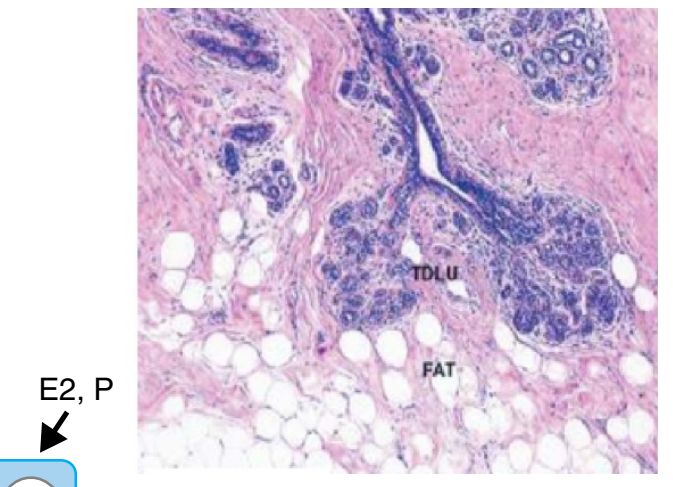

Luminal cell

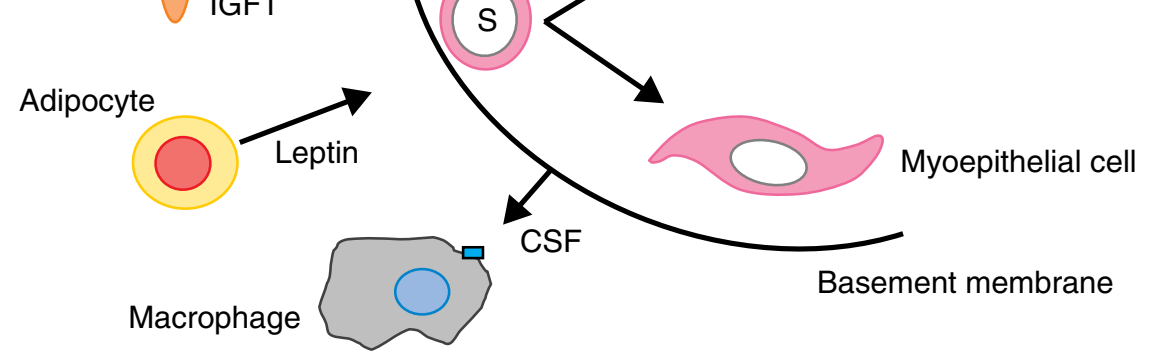

Figure 3 Features of the normal breast. (a) Electron micrograph of a ductule of the breast. (b) Section of lobules of the breast showing a relationship with collagenous and fatty stroma. Reprinted with permission from the American Association for Cancer Research [166]. (c) A simplified cartoon of reported potential interactions between three cell types in the stroma and the epithelium of the breast. CSF, colony-stimulating factor; ER, estrogen receptor; IGF1, insulin-like growth factor 1; PR, progesterone receptor; PTH, parathyroid hormone; TDLU, terminal duct lobular unit.

has come from an understanding of the biology of the ER and the knowledge that estrogen is synthesized in the breast and elsewhere after ovarian function decreases at menopause. These data have led to the introduction of the SERMs (tamoxifen and raloxifene) and the potential introduction of AIs (exemestane and anastrozole) for breast cancer prevention. Tamoxifen acts by blocking the ER but under certain circumstances can change to being a partial agonist via the ER and this may limit its preventive utility since in some women at increased risk it appears to increase mammographic density [127]. The development of orally active ER downregulators similar to fulvestrant (which has to be given intramuscularly, thus limiting its preventive utility) may be superior to tamoxifen (for example, ARN-810, NCTO1823835) [128]. Another potential way to enhance the therapeutic ratio of tamoxifen is to use low doses or to combine tamoxifen with retinoids such as fenretinide; studies of these approaches are under way in prevention trials in Italy [129]. Another approach may be a combination with low-dose aspirin, which has some minor preventive effects on breast cancer risk but would help combat the increased risks of thromboembolic disease with tamoxifen.

\section{Mimicking the protective effects of an early first pregnancy}

Recent insights into the effects of early first pregnancy of the normal breast in young women give clues to how we might mimic this effect therapeutically. Since the demonstration that $\mathrm{ER}^{+}$and progesterone receptor-positive $\left(\mathrm{PR}^{+}\right)$cells in the normal breast rarely proliferate [130], it has been shown, for example, that progesterone binds to its receptor on the PR of the epithelial cell and stimulates the synthesis and release of paracrine mediators such as Rank (receptor activator of nuclear factor-kappa-B), Wnt (wingless related integration site), and growth hormone, which in turn stimulate adjacent stem and progenitor cell expansion [131,132]. Recently, it was shown that early first pregnancy in women reduces the number of $\mathrm{PR}^{+}$ cells and downregulation of paracrine mediators, resulting in a reduction of the stem/progenitor cell compartment [133]. These data suggest that modulating the effect 
of progesterone by the use of antiprogestins should be explored for breast cancer prevention [134].

Establishing the cause of the inverse association between childhood/adolescent obesity and lower risk of breast cancer

Observational data have linked diet and growth in height in childhood and dietary exposures during early adulthood (that is, between menarche and first full-term pregnancy to later risk of breast cancer). These studies have either used retrospective recall of early life exposures from adults or prospectively assessed short-term effects on surrogate risk markers like benign breast disease [135]. Studying lifestyle exposures in this period is a challenge which has understandably received less research attention than exposures later in life. The period between menarche and first full-term pregnancy is a priority for research since risk can accumulate rapidly in this period until terminal differentiation that accompanies first pregnancy.

Key observations which deserve further study are the reduced breast cancer risk with a higher BMI in early adulthood (that is, at the age of 18 to 21), reported from numerous prospective studies among Caucasian [136,137], black [138], and Asian [139] populations. This observation is partly explained by smaller adult weight gains, which are consistently reported among heavier young women [140-143]. Other possible mechanisms which may put heavier women at lower risk than their lean counterparts include higher estrogen levels, which may upregulate the $B R C A 1$ tumor-suppressor gene, earlier differentiation of breast tissue [9], subsequent lower IGF-1 levels in adulthood [144], and a slower pubertal growth and sexual maturation despite their early menarche [135]. Increased irregular cycles are often cited as a likely protective mechanism but are not supported by available data [145]. Likewise, height velocity has been linked to risk of breast cancer [146] and benign breast disease [147], which in turn may be linked to dietary patterns which are high in animal versus vegetable protein and lower in fiber and isoflavones [148].

\section{Reversing the promotional effects of late pregnancy}

Late pregnancy is a major driver of the worldwide increase in breast cancer incidence. Over half of women in the UK have their first pregnancy over the age of 30, and thus understanding the mechanism of its effect on risk is of great importance. It seems likely that the breasts of older fertile women harbor early pre-cancerous lesions. One mechanism in which these may be stimulated is as a result of immunological processes that occur during post-partum breast involution. Lyons and colleagues [149] demonstrated an increase in cyclooxygenase 2 during involutional macrophage infiltration and showed that ibuprofen reduces post-partum breast cancer in these models. Ibuprofen might be tested in women at high risk because of late pregnancy and a positive family history $[148,149]$. Premalignant lesions in the breast have indeed been detected by review of serial sections of the breasts at post-mortem of older premenopausal women and found to be present in up to one third of women $[150,151]$. It is clear that most do not progress to breast cancer since the incidence of the disease is not that high. Recently, Haricharan and colleagues [152] demonstrated that the signal transduction molecule pSTAT5 (phospho-signal transducer and activator of transcription 5) is activated by inhibiting apoptosis in premalignant lesions that progress to forming cancer. Inhibitors of this pathway are in the clinic and ultimately could be used for prevention [153].

\section{Failure of menopausal breast involution}

The lobules of the breast undergo involution after menopause. However, Wellings and colleagues [154] reported atypical premalignant lobules which persisted after menopause where menopausal regression might be expected. Investigators at the Mayo Clinic noted, by careful histological examination of biopsies of the breast of post-menopausal women, that the breast lobules in some women did not undergo post-menopausal involution and that these women were at high risk of subsequent breast cancer [155]. As a measure of the importance of this observation, the authors investigated how the lack of involution compared with risk prediction of the Gail model in this group of women. The C-statistic for the Gail model of the patients studied was 0.60. For lobular involution (or not), the $\mathrm{C}$-statistic was 0.66. Combining Gail risk and involution did not change the latter figure [156]. There are, as far as we are aware, no published data on the mechanism of lack of post-menopausal involution but this may be similar to the lack of involution after a pregnancy [152]. The reduction of apoptosis reported in animal models of pregnancy involution was reported in women [157]. In the clinic, there are agents to enhance apoptosis, such as ABT-263, with potential for transfer to prevention if toxicity could be reduced [158].

\section{Mechanism of mammographic density}

Some studies show that the rate of the well-known decline of mammographic density with age is slower in some women and indicates higher breast cancer risk $[159,160]$. Methods to reduce density may prevent breast cancer. As proof of principle of this hypothesis, Cuzick and colleagues [127] demonstrated in the IBIS-I prevention trial that women who had a more than $10 \%$ reduction in density with tamoxifen had a $70 \%$ reduction in risk of breast cancer risk but that for women with less or no reduction in density there was no reduction in risk. Investigation of the reasons for the lack of effect of 
age and of tamoxifen on some breasts is clearly important [161].

Gene expression profiles of fibroblasts derived from dense and non-dense areas of the breast indicate marked differences in expression. Expression of genes associated with inflammation (such as c-Jun N-terminal kinases, or JNK) and several signaling pathways is upregulated and suggests the use of, for example, JNK inhibitors, already in the clinic for treatment of overt disease [162,163]. Some fibroblasts in dense areas resemble cancer-associated fibroblasts in their signaling pathways and production of extracellular aligned collagen, all potential targets for prevention [164].

\section{Energy restriction mimetics}

Energy restriction is well known to increase longevity in several types of organisms, in part by reducing the incidence of cancer. It acts predominantly by reversing the effects of obesity on inflammation, certain signal transduction pathways, and insulin/IGF-1 [165]. Obesity is associated with macrophage infiltration and activation in fat, which in turn results in cytokine production and increased aromatase activity and estrogen production [166,167]. Obesity also results in reduced insulin sensitivity and altered signal transduction pathways, such as P13Kinase and mammalian target of rapamycin (mTOR), and in mitochondrial metabolism $[168,169]$. Some agents which beneficially reduce activity of these pathways such as mTOR inhibitors are already in the clinic, and others such as metformin and SIRT 1 activators such as resveratol and other activators of sirtuins are under investigation [170]. Doubt has been cast on the value of metformin [171], giving added importance to the randomized trial of adjuvant metformin instigated by Goodwin and colleagues [172].

\section{Physical activity}

Several biological mechanisms have been proposed to explain the inverse association between PA and breast cancer risk. Although regular exercise may delay the onset of menarche, increase the length of the menstrual cycle, or increase the number of anovulatory cycles, hence reducing exposure to sex hormones, prospective intervention studies suggest that high levels of exercise may be needed to induce menstrual cycle changes [173,174]. Other possible mechanisms include improvements in insulin sensitivity, immune function/surveillance, and antioxidant defense capacity as well as alterations in gene function or apoptosis $[175,176]$. Studies have also highlighted a potential role for epigenetic mechanisms which could reduce breast cancer risk in physically active women, including an increase in LINE-1 (long interspersed nucleotide elements-1) methylation (index of global DNA methylation) and an increase in the methylation of tumor-suppressor genes
[176,177]. Moderate levels of PA may also increase the expression of telomere-stabilizing proteins, thereby attenuating the effects of aging on telomere length and potentially reducing the risk of age-related diseases such as breast cancer $[178,179]$.

PA could also influence breast cancer risk through its effect on weight loss and reduced levels of body fat. This means that distinguishing the independent effects of PA on breast cancer risk is difficult because body fat reduction impacts a range of putative breast cancer risk markers, including circulating levels of sex hormones, insulin-like growth factors, adipokines, and inflammatory mediators [173]. Elevated circulating levels of adipokines such as leptin, interleukin-6, and tumor necrosis factoralpha and the acute phase protein C-reactive protein as well as reduced levels of adiponectin are associated with high levels of body fat $[173,180]$, whereas weight loss interventions involving PA evoke reductions in circulating levels of inflammatory markers and leptin while increasing circulating levels of adiponectin [181,182]. Despite this, evidence from both human $[173,174]$ and animal $[175,183]$ studies suggests that regular aerobic exercise can induce changes in biological risk factors (for example, sex hormones, insulin sensitivity, antioxidant defense capacity, and intracellular signaling pathways) that are independent of PA-induced changes in body weight and body composition.

The studies outlined above indicate the interactions which occur between epithelial cells and between them and stromal cells such as macrophages, fibroblasts, and adipocytes (Figure 3). They indicate the potential for new approaches to prevention, although translation to the clinic will be difficult. An excellent discussion of the problems is given by Strasser-Weippl and Goss [184].

\section{Clinical application Guidelines \\ Preventive therapy}

Several guidelines advise how we might apply the knowledge that we have gained concerning hormonal prevention (tamoxifen, raloxifene, exemestane, and anastrozole) and lifestyle factors (weight control, exercise, and limitation of alcohol) to populations of women. Hormonal chemoprevention is suggested for women at increased risk, whereas lifestyle factors can be applied to all women since all are at some risk of breast cancer, and even at low risk, lifestyle factors are similar to those which help prevent other conditions such as CVDs and diabetes.

Three major sets of clinical guidelines were published concerning the selection of women for chemoprevention in 2013. The US Preventive Service Task Force gives guidelines for prescription of medication for risk reduction of breast cancer [185]. The recommendation applies to asymptomatic women 35 years or older without a prior 
diagnosis of breast cancer, ductal carcinoma in situ, or lobular carcinoma in situ. They advise use of the Gail model to assess risks and a cutoff of 1.66\% 5-year risk. However, taking toxicity into account, they suggest that a threshold for advising treatment of 3\% 5-year risk may be more appropriate and advise use of the tables published by Freedman and colleagues [186] and, as in the tables, that the balance for use/no use depends on age, race/ ethnicity, the medication used, and whether the woman has a uterus.

The American Society of Clinical Oncology published their clinical practice guideline in August 2013 [187]. The report included a systematic review of randomized controlled trials and meta-analyses published between 2007 and 2013 which identified 19 trials and six chemoprevention agents. In women who are at increased risk of breast cancer and who are more than 35 years old, they suggest that tamoxifen ( $20 \mathrm{mg}$ per day for 5 years) be discussed as an option to reduce the risk of $\mathrm{ER}^{+}$breast cancer. In post-menopausal women, raloxifene $(60 \mathrm{mg}$ per day for 5 years) and exemestane (25 $\mathrm{mg}$ per day for 5 years) should also be discussed as options for breast cancer risk reduction. Those at increased breast cancer risk are defined as individuals with a 5-year projected absolute risk of breast cancer of more than $1.66 \%$ (based on the National Cancer Institute Breast Cancer Risk Assessment Tool or an equivalent measure) or women diagnosed with lobular carcinoma in situ. SERMs are not recommended for use in women with a history of deep vein thrombosis, pulmonary embolus, stroke, or transient ischemic attack or during prolonged immobilization or in combination with HRT. In this update of the guideline published in 2009, the phrase 'may be offered' was replaced by 'should be discussed as an option' in women at increased risk of breast cancer [187]. The American Society of Clinical Oncology reviewers concluded that 'research is needed to address the many unresolved issues related to the poor uptake of breast cancer chemoprevention agents in women who are at increased risk. These include (1) the design of effective tools and approaches to educate providers on the option of chemoprevention, (2) efficacious interventions that communicate to eligible women the risks and benefits of specific chemoprevention agents, (3) the development of tools that more accurately identify women at increased risk, and (4) a greater understanding of what disparities and barriers exist with regard to chemoprevention use among women at higher risk for breast cancer' [187]. The document provides in-depth reviews of all of the important trials.

The UK National Institute of Health and Care Excellence published guidelines for women at increased risk of breast cancer by virtue of a family history of the disease [188]. For the first time in the UK, their recommendation was that women at greater than $30 \%$ (1 in 3-4+) lifetime risk of breast cancer be 'offered' tamoxifen or raloxifene and that in those at greater than $17 \%$ (1 in 6+) lifetime risk preventive therapy be 'considered' for treatment. They did not endorse use of AIs, since the IBIS-2 study had not been published at the time, but did suggest that a lifestyle advice leaflet be given.

\section{Lifestyle change}

The ACS published guidelines on nutrition and PA measures for cancer prevention in 2012 [189]. The guidelines were based on published data. Randomized controlled trials were given greatest credence and cohort studies over case-control studies. Four lifestyle choices were recommended to reduce cancer risk: (a) achieve and maintain a healthy weight throughout life, (b) adopt a physically active lifestyle, (c) consume a healthy diet, with an emphasis on plant foods, and (d) limit consumption of alcoholic beverages.

Importantly, recommendations were also made for introduction of the guidelines into the community: 'Public, private, and community organizations should work collaboratively at national, state, and local levels to implement policy and environmental changes...' [190].

The Second WCRF/AICR Expert Report (Food, Nutrition, Physical Activity, and the Prevention of Cancer: A Global Perspective) was published in 2007 [117] and is continually updated [190]. The recommendations are similar to the ACS guidelines and are relevant to the prevention of other conditions such as CVD.

\section{Implementation}

The guidelines outlined above are based on the best available knowledge and seem eminently sensible. It is widely appreciated that their implementation is a major and longterm problem. Although several models give reasonable indicators of risk of breast cancer, detecting women at risk in the population is problematic. For example, women with only a minor family history but with endocrine risk factors are very often not aware of their breast cancer risks. One solution is to use mammographic screening programs as a time to communicate risk information (including lifestyle parameters) and to highlight/signpost access to preventive therapy lifestyle programs $[58,191]$. In a program in Manchester, UK, collecting risk information at screening was shown to be feasible, and $95 \%$ of women indicated that they wished to know their risks of breast cancer [58]. Women at high risk can be offered preventive therapy in the context of specialist clinics, but on a population basis it may be optimal to implement risk assessment and treatment in general practitioner practices as is the case for the prevention of CVD in clinical practice.

For lifestyle change, the goals for breast cancer prevention are the same as those required to solve the obesity 
epidemic. These are very well highlighted in the goals set by the US Institute of Medicine report on 'Accelerating Progress in Obesity Prevention: Solving the Weight of the Nation' [192]. The goals of the program encompassed integrating PA as a routine into everyday life, making healthy foods and beverages available everywhere, marketing messages pertaining to healthy nutrition and PA and expansion of the role of health-care providers, insurers, employers, and schools as national focal points for obesity prevention. The national (US) progress of this very broad and crucial program was summarized in a recent workshop [193]. The US Institute of Medicine believes that the obesity problem will be solved only by mobilizing the population of all ages for there to be an accelerated transformation to the obesity problem (Figure 4). The documents suggest groundbreaking approaches; similar ones could be adapted to other developed and developing countries.

Colditz and colleagues [194] recently summarized the critical barriers to change for the prevention of cancer in general. These included (a) skepticism that cancer can be prevented, (b) the short-term focus of cancer research, (c) interventions deployed too late in life, (d) research focus on treatment not prevention, (e) debates among scientists, (f) societal factors which affect health outcomes, (g) lack of transdiciplinary approaches, and (h) the complexity of successful implementation. These are barriers to be overcome.

\section{Conclusions}

One conclusion of this review is that the application of measures that are already available, such as chemoprevention and lifestyle prevention, would result in appreciable reductions in breast cancer risk. A second conclusion is that the pace of advance of our understanding of the biology of breast cancer risk and development is highly likely to give rise to new avenues for prevention over the next 10 years. A major problem is applying what we already know concerning the efficacy of prevention to appropriate populations of women. To apply chemoprevention, we need to have measures in place to assess risk and to explain the pros and cons of treatment and for prescription of appropriate therapies. Lifestyle change is a population problem which involves publicity concerning its risks and benefits of change and providing mechanisms to support women in their choices throughout society as highlighted in the US Institute of Medicine documents.

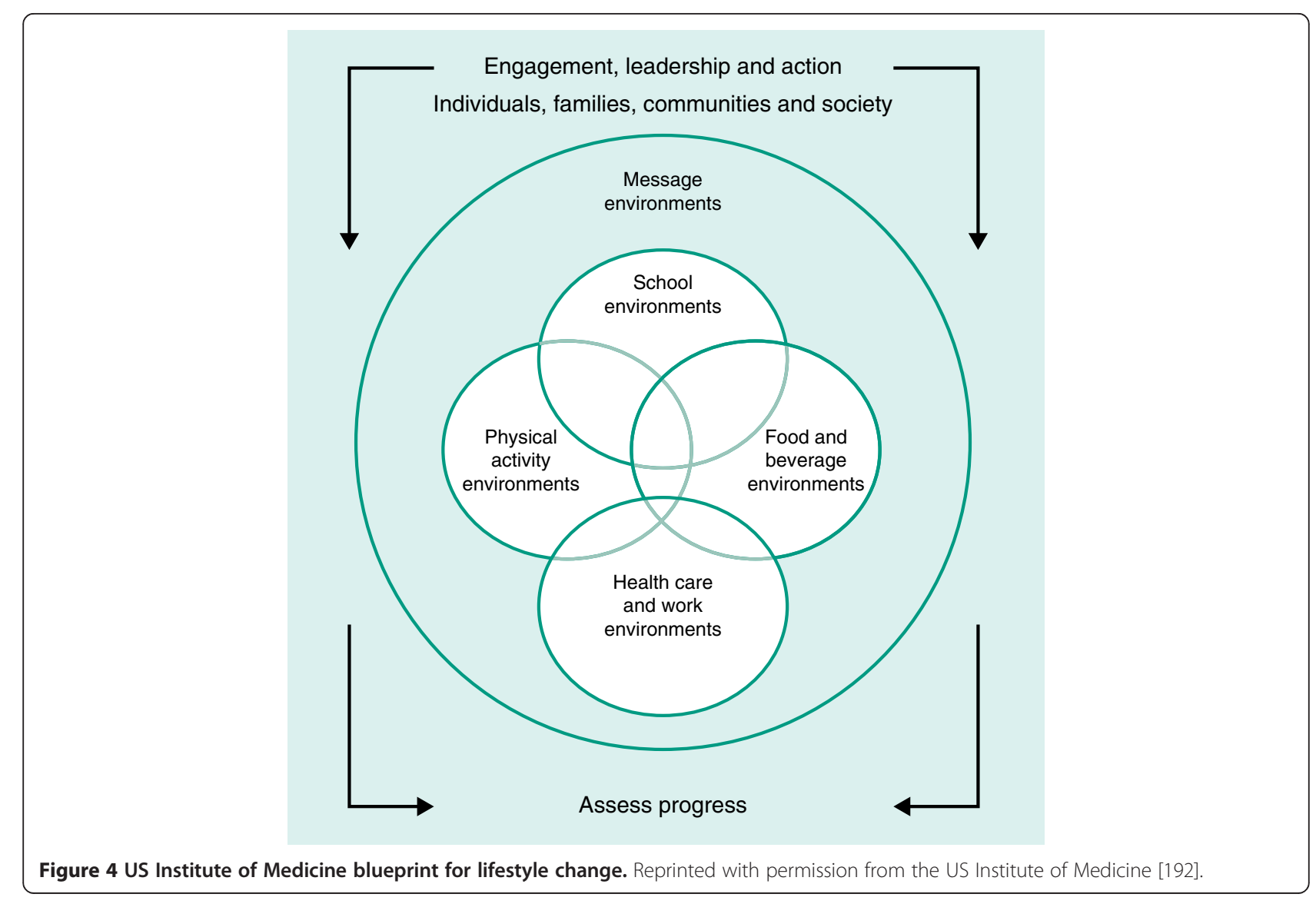




\section{Abbreviations}

ACS: American cancer society; Al: Aromatase inhibitor; AICR: American institute for cancer research; AUC: Area under the receiver operating curve; BI-RADS: Breast imaging reporting and data system; BMI: Body mass index; BOADICEA: The breast and ovarian analysis of disease incidence and carrier estimation algorithm; BRCA1/2: Breast cancer 1/2; Cl: Confidence interval; C-statistic: Area under the receiver operating curve; CVD: Cardiovascular disease; ER: Estrogen receptor; HRT: Hormone replacement therapy; IBIS: International breast cancer intervention study; IGF-1: Insulin-like growth factor-1; JNK: c-Jun N-terminal kinases; mTOR: mammalian target of rapamycin; PA: Physical activity; PR: Progesterone receptor; SERM: Selective estrogen receptor modulator; SNP: Single-nucleotide polymorphism; STAR: Study of tamoxifen and raloxifene; WCRF: World cancer research fund; WHI: Women's health initiative.

\section{Competing interests}

The authors declare that they have no competing interests.

\section{Authors' contributions}

$\mathrm{AH}$ wrote the first draft of the review, and all authors commented on and amended the draft. All authors read and approved the final manuscript.

\section{Acknowledgments}

The authors would like to acknowledge the help given by Breast Cancer Campaign staff during the production of this review.

\section{Author details}

${ }^{1}$ Genesis Breast Cancer Prevention Centre, University Hospital of South Manchester, Southmoor Road, Wythenshawe, Manchester M29 9LT, UK. ${ }^{2}$ The Christie, NHS Foundation Trust, Wilmslow Road, Manchester M20 2QJ, UK. ${ }^{3}$ Breakthrough Breast Cancer Research Unit, Institute of Cancer Sciences, University of Manchester, Wilmslow Road, Manchester M20 2QJ, UK. ${ }^{4}$ Centre for Public Health Nutrition Research, Division of Cancer Research, Level 7, Mailbox 7, University of Dundee, Ninewells Hospital \& Medical School, George Pirie Way, Dundee DD1 9SY, UK. ${ }^{5}$ Centre for Cancer Prevention, Wolfson Institute of Preventive Medicine, Queen Mary University of London, Charterhouse Square, London EC1M 6BQ, UK. ${ }^{6}$ Manchester Centre for Genomic Medicine, The University of Manchester, Manchester Academic Health Science Centre, Central Manchester Foundation Trust, St. Mary's Hospital, Oxford Road, Manchester M13 9WL, UK. ${ }^{7}$ Division of Genetics and Epidemiology, Institute of Cancer Research, Cotswold Road, Sutton, London SM2 5NG, UK. ${ }^{8}$ Department of Cancer Studies and Molecular Medicine, University of Leicester, University Road, Leicester LE2 7LX, UK. ${ }^{9}$ Cancer Epidemiology Unit, Nuffield Department of Population Health, University of Oxford, Richard Doll Building, Roosevelt Drive, Oxford OX3 7LF, UK. ${ }^{10}$ School of Health Sciences, Faculty of Medicine and Health Sciences, University of East Anglia, University Drive, Norwich NR4 7TJ, UK.

\section{Published online: 28 September 2014}

\section{References}

1. Eccles SA, Aboagye EO, Ali S, Anderson AS, Armes J, Berditchevski F, Blaydes JP, Brennan K, Brown NJ, Bryant HE, Bundred NJ, Burchell JM, Campbell AM, Carroll JS, Clarke RB, Coles CE, Cook GJ, Cox A, Curtin NJ, Dekker LV, Silva Idos S, Duffy SW, Easton DF, Eccles DM, Edwards DR, Edwards J, Evans D, Fenlon DF, Flanagan JM: Critical research gaps and translational priorities for the successful prevention and treatment of breast cancer. Breast Cancer Res 2013, 15:R92.

2. Arnold M, Karim-Kos HE, Coebergh JW, Byrnes G, Antilla A, Ferlay J, Renehan $A G$, Forman D, Soerjomataram I: Recent trends in incidence of five common cancers in 26 European countries since 1988: Analysis of the European Cancer Observatory. Eur J Cancer 2013.

3. Rahib L, Smith BD, Aizenberg R, Rosenzweig AB, Fleshman JM, Matrisian LM: Projecting cancer incidence and deaths to 2030: the unexpected burden of thyroid, liver, and pancreas cancers in the United States. Cancer Res 2014, 74:2913-2921.

4. Colditz GA, Bohlke K: Priorities for the primary prevention of breast cancer. CA Cancer J Clin 2014, 64:186-194.

5. Tryggvadottir L, Sigvaldason H, Olafsdottir GH, Jonasson JG, Jonsson $T$, Tulinius H, Eyfjörd JE: Population-based study of changing breast cancer risk in Icelandic BRCA2 mutation carriers, 1920-2000. J Natl Cancer Inst 2006, 98:116-122.

6. King MC, Motulsky AG: Human genetics. Mapping human history. Science 2002, 298:2342-2343.

7. Evans DG, Shenton A, Woodward E, Lalloo F, Howell A, Maher ER: Penetrance estimates for BRCA1 and BRCA2 based on genetic testing in a Clinical Cancer Genetics service setting: risks of breast/ovarian cancer quoted should reflect the cancer burden in the family. BMC Cancer 2008, 8:155.

8. Collaborative Group on Hormonal Factors in Breast Cancer: Breast cancer and breastfeeding: collaborative reanalysis of individual data from 47 epidemiological studies in 30 countries, including 50302 women with breast cancer and 96973 women without the disease. Lancet 2002, 360:187-195.

9. Cuzick J, Sestak I, Bonanni B, Costantino JP, Cummings S, DeCensi A, Dowsett M, Forbes JF, Ford L, LaCroix AZ, Mershon J, Mitlak BH, Powles T, Veronesi U, Vogel V, Wickerham DL, SERM Chemoprevention of Breast Cancer Overview Group: Selective oestrogen receptor modulators in prevention of breast cancer: an updated meta-analysis of individual participant data. Lancet 2013, 381:1827-1834.

10. Goss PE, Ingle JN, Ales-Martinez JE, Cheung AM, Chlebowski RT, Wactawski-Wende J, MCTiernan A, Robbins J, Johnson KC, Martin LW, Winquist E, Sarto GE, Garber JE, Fabian CJ, Pujol P, Maunsell E, Farmer P, Gelmon KA, Tu D, Richardson H, NCIC CTG MAP.3 Study Investigators: Exemestane for breast-cancer prevention in post-menopausal women. N Engl J Med 2011, 64:2381-2391.

11. Cuzick J, Sestak I, Forbes JF, Dowsett M, Knox J, Cawthorn S, Saunders C, Roche N, Mansel RE, von Minckwitz G, Bonanni B, Palva T, Howell A: IBIS-II investigators: Anastrozole for prevention of breast cancer in high-risk post-menopausal women (IBIS-II): an international, double-blind, randomised placebo-controlled trial. Lancet 2014, 383:1041-1048.

12. Brown P: Prevention: targeted therapy-anastrozole prevents breast cancer. Nat Rev Clin Oncol 2014, 11:127-128.

13. Jemal A, Siegel R, Ward E, Murray T, Xu J, Thun MJ: Cancer statistics, 2007 CA Cancer J Clin 2007, 57:43-66.

14. Parkin DM, Boyd L, Walker LC: The fraction of cancer attributable to lifestyle and environmental factors in the UK in 2010. Br J Cancer 2011, 105:S77-S81.

15. Amir E, Freedman OC, Seruga B, Evans DG: Assessing women at high risk of breast cancer: a review of risk assessment models. J Natl Cancer Inst 2010, 102:680-691.

16. Meads C, Ahmed I, Riley RD: A systematic review of breast cancer incidence risk prediction models with meta-analysis of their performance. Breast Cancer Res Treat 2012, 132:365-377.

17. Fischer C, Kuchenbäcker K, Engel C, Zachariae S, Rhiem K, Meindl A, Rahner N, Dikow N, Plendl H, Debatin I, Grimm T, Gadzicki D, Flöttmann R, Horvath J, Schröck E, Stock F, Schäfer D, Schwaab I, Kartsonaki C, Mavaddat N, Schlegelberger B, Antoniou AC, Schmutzler R: German Consortium for Hereditary Breast and Ovarian Cancer: Evaluating the performance of the breast cancer genetic risk models BOADICEA, IBIS, BRCAPRO and Claus for predicting BRCA1/2 mutation carrier probabilities: a study based on 7352 families from the German Hereditary Breast and Ovarian Cancer Consortium. J Med Genet 2013, 50:360-367.

18. Evans DG, Lalloo F, Cramer A, Jones EA, Knox F, Amir E, Howell A: Addition of pathology and biomarker information significantly improves the performance of the Manchester scoring system for BRCA1 and BRCA2 testing. J Med Genet 2009, 46:811-817.

19. Kast K, Schmutzler RK, Rhiem K, Kiechle M, Fischer C, Niederacher D, Arnold N, Grimm T, Speiser D, Schlegelberger B, Varga D, Horvath J, Beer M, Briest $S$, Meindl A, Engel C: Validation of the Manchester scoring system for predicting BRCA1/2 mutations in 9,390 families suspected of having hereditary breast and ovarian cancer. Int J Cancer 2014. [Epub ahead of print].

20. Tyrer J, Duffy SW, Cuzick J: A breast cancer prediction model incorporating familial and personal risk factors. Stat Med 2004, 23:1111-1130.

21. Gail MH, Brinton LA, Byar DP, Corle DK, Green SB, Schairer C, Mulvihill JJ: Projecting individualized probabilities of developing breast cancer for white females who are being examined annually. J Natl Cancer Inst 1989, 81:1879-1886.

22. MacInnis RJ, Bickerstaffe A, Apicella C, Dite GS, Dowty JG, Aujard K, Phillips KA, Weideman P, Lee A, Terry MB, Giles GG, Southey MC, Antoniou AC, 
Hopper JL: Prospective validation of the breast cancer risk prediction model BOADICEA and a batch-mode version BOADICEACentre. $\mathrm{Br} J$ Cancer 2013, 109:1296-1301.

23. Evans DG, Ingham S, Dawe $S$, Roberts L, Lalloo F, Brentnall AR, Stavrinos $P$ Howell A: Breast cancer risk assessment in 8,824 women attending a family history evaluation and screening programme. Fam Cancer 2014, 13:189-196.

24. Rosner BA, Colditz GA, Hankinson SE, Sullivan-Halley J, Lacey JV Jr, Bernstein $L$ : Validation of Rosner-Colditz breast cancer incidence model using an independent data set, the California Teachers Study. Breast Cancer Res Treat 2013, 142:187-202.

25. Costantino JP, Gail MH, Pee D, Anderson S, Redmond CK, Benichou J, Wieand HS: Validation studies for models projecting the risk of invasive and total breast cancer incidence. J Natl Cancer Inst 1999, 91:1541-1548.

26. Schonfeld SJ, Pee D, Greenlee RT, Hartge P, Lacey JV Jr, Park Y, Schatzkin A Visvanathan K, Pfeiffer RM: Effect of changing breast cancer incidence rates on the calibration of the Gail model. J Clin Oncol 2010, 28:2411-2417.

27. Amir E, Evans DG, Shenton A, Lalloo F, Moran A, Boggis C, Wilson M, Howell A: Evaluation of breast cancer risk assessment packages in the family history evaluation and screening programme. J Med Genet 2003, 40:807-814.

28. Quante AS, Whittemore AS, Shriver T, Strauch K, Terry MB: Breast cancer risk assessment across the risk continuum: genetic and nongenetic risk factors contributing to differential model performance. Breast Cancer Res 2012, 14:R144

29. Powell M, Jamshidian F, Cheyne K, Nititham J, Prebil LA, Ereman R: Assessing breast cancer risk models in Marin County, a population with high rates of delayed childbirth. Clin Breast Cancer 2014, 14:212-220.

30. Huo CW, Chew GL, Britt KL, Ingman WV, Henderson MA, Hopper JL, Thompson EW: Mammographic density-a review on the current understanding of its association with breast cancer. Breast Cancer Res Treat 2014, 144:479-502

31. Cummings SR, Tice JA, Bauer S, Browner WS, Cuzick J, Ziv E, Vogel V, Shepherd J, Vachon C, Smith-Bindman R, Kerlikowske K: Prevention of breast cancer in post-menopausal women: approaches to estimating and reducing risk. J Natl Cancer Inst 2009, 101:384-398.

32. Michailidou K, Hall P, Gonzalez-Neira A, Ghoussaini M, Dennis J, Milne RL, Schmidt MK, Chang-Claude J, Bojesen SE, Bolla MK, Wang Q, Dicks E, Lee A Turnbull C, Breast and Ovarian Cancer Susceptibility Collaboration, Rahman N, Fletcher O, Peto J, Gibson L, Dos Santos Silva I, Nevanlinna H, Muranen TA, Aittomäki K, Blomqvist C, Czene K, Irwanto A, Liu J, Waisfisz Q, Meijers-Heijboer H, Adank M: Large-scale genotyping identifies 41 new loci associated with breast cancer risk. Nat Genet 2013, 45:353-361.

33. Burton $\mathrm{H}$, Chowdhury S, Dent T, Hall A, Pashayan N, Pharoah P: Public health implications from COGS and potential for risk stratification and screening. Nat Genet 2013, 45:349-351.

34. Hormones E, Group BCC, Key TJ, Appleby PN, Reeves GK, Roddam AW, Helzlsouer KJ, Alberg AJ, Rollison DE, Dorgan JF, Brinton LA, Overvad K, Kaaks R, Trichopoulou A, Clavel-Chapelon F, Panico S, Duell EJ, Peeters PH, Rinaldi S, Fentiman IS, Dowsett M, Manjer J, Lenner P, Hallmans G, Baglietto L, English DR, Giles GG, Hopper JL, Severi G, Morris HA, et al: Circulating sex hormones and breast cancer risk factors in post-menopausal women: reanalysis of 13 studies. Br J Cancer 2011, 105:709-722.

35. McCormack VA, dos Santos SI: Breast density and parenchymal patterns as markers of breast cancer risk: a meta-analysis. Cancer Epidemiol Biomarkers Prev 2006, 15:1159-1169.

36. Tice JA, Cummings SR, Ziv E, Kerlikowske K: Mammographic breast density and the Gail model for breast cancer risk prediction in a screening population. Breast Cancer Res Treat 2005, 94:115-122.

37. Barlow WE, White E, Ballard-Barbash R, Vacek PM, Titus-Ernstoff L, Carney PA, Tice JA, Buist DS, Geller BM, Rosenberg R, Yankaskas BC, Kerlikowske K: Prospective breast cancer risk prediction model for women undergoing screening mammography. J Natl Cancer Inst 2006, 98:1204-1214

38. Chen J, Pee D, Ayyagari R, Graubard B, Schairer C, Byrne C, Benichou J, Gail $\mathrm{MH}$ : Projecting absolute invasive breast cancer risk in white women with a model that includes mammographic density. J Natl Cancer Inst 2006, 98:1215-1226

39. Tice JA, Cummings SR, Smith-Bindman R, Ichikawa L, Barlow WE, Kerlikowske $\mathrm{K}$ : Using clinical factors and mammographic breast density to estimate breast cancer risk: development and validation of a new predictive model. Ann Intern Med 2008, 148:337-347.
40. Cecchini RS, Costantino JP, Cauley JA, Cronin WM, Wickerham DL, Bandos H, Weissfeld $J$, Wolmark N: Baseline mammographic breast density and the risk of invasive breast cancer in post-menopausal women participating in the NSABP study of tamoxifen and raloxifene (STAR). Cancer Prev Res 2012, 5:1321-1329.

41. Vachon CM, Fowler EE, Tiffenberg G, Scott CG, Pankratz VS, Sellers TA, Heine $\mathrm{JJ}$ : Comparison of percent density from raw and processed full-field digital mammography data. Breast Cancer Res 2013, 15:R1.

42. Keller BM, Chen J, Conant EF, Kontos D: Breast density and parenchymal texture measures as potential risk factors for estrogen-receptor positive breast cancer. Proc SPIE 2014, 9035:90351D.

43. Cheddad A, Czene K, Shepherd JA, Li J, Hall P, Humphreys K: Enhancement of mammographic density measures in breast cancer risk prediction. Cancer Epidemiol Biomarkers Prev 2014, 23:1314-1323.

44. Zheng B, Sumkin JH, Zuley ML, Wang X, Klym AH, Gur D: Bilateral mammographic density asymmetry and breast cancer risk: a preliminary assessment. Eur J Radiol 2012, 81:3222-3228.

45. Byng JW, Boyd NF, Fishell E, Jong RA, Yaffe MJ: The quantitative analysis of mammographic densities. Phys Med Biol 1994, 39:1629-1638.

46. Pettersson A, Graff RE, Ursin G, Santos Silva ID, McCormack V, Baglietto L, Vachon C, Bakker MF, Giles GG, Chia KS, Czene K, Eriksson L, Hall P, Hartman M, Warren RM, Hislop G, Chiarelli AM, Hopper JL, Krishnan K, Li J, Li Q, Pagano I, Rosner BA, Wong CS, Scott C, Stone J, Maskarinec G, Boyd NF, van Gils CH, Tamimi RM: Mammographic density phenotypes and risk of breast cancer: a meta-analysis. J Natl Cancer Inst 2014, 106:dju078.

47. Nickson C, Arzhaeva Y, Aitken Z, Elgindy T, Buckley M, Li M, English DR, Kavanagh AM: AutoDensity: an automated method to measure mammographic breast density that predicts breast cancer risk and screening outcomes. Breast Cancer Res 2013, 15:R80.

48. Shepherd JA, Kerlikowske K, Ma L, Duewer F, Fan B, Wang J, Malkov S, Vittinghoff $E$, Cummings SR: Volume of mammographic density and risk of breast cancer. Cancer Epidemiol Biomarkers Prev 2011, 20:1473-1482.

49. Wang J, Azziz A, Fan B, Malkov S, Klifa C, Newitt D, Yitta S, Hylton N, Kerlikowske K, Shepherd JA: Agreement of mammographic measures of volumetric breast density to MRI. PLoS One 2013, 8:e81653.

50. Gubern-Mérida A, Kallenberg M, Platel B, Mann RM, Martí R, Karssemeijer N: Volumetric breast density estimation from full-field digital mammograms: a validation study. PLOS One 2014, 9:e85952.

51. Pharoah PD, Antoniou AC, Easton DF, Ponder BA: Polygenes, risk prediction, and targeted prevention of breast cancer. N Engl J Med 2008, 358:2796-2803.

52. Mealiffe ME, Stokowski RP, Rhees BK, Prentice RL, Pettinger M, Hinds DA: Assessment of clinical validity of a breast cancer risk model combining genetic and clinical information. J Natl Cancer Inst 2010, 102:1618-1627.

53. Wacholder S, Hartge P, Prentice R, Garcia-Closas M, Feigelson HS, Diver WR, Thun MJ, Cox DG, Hankinson SE, Kraft P, Rosner B, Berg CD, Brinton LA, Lissowska J, Sherman ME, Chlebowski R, Kooperberg C, Jackson RD, Buckman DW, Hui P, Pfeiffer R, Jacobs KB, Thomas GD, Hoover RN, Gail MH, Chanock SJ, Hunter DJ: Performance of common genetic variants in breast-cancer risk models. N Engl J Med 2010, 362:986-993.

54. Gail MH: Value of adding single-nucleotide polymorphism genotypes to a breast cancer risk model. J Natl Cancer Inst 2009, 101:959-963.

55. Dite GS, Mahmoodi M, Bickerstaffe A, Hammet F, Macinnis RJ, Tsimiklis H, Dowty JG, Apicella C, Phillips KA, Giles GG, Southey MC, Hopper JL: Using SNP genotypes to improve the discrimination of a simple breast cancer risk prediction model. Breast Cancer Res Treat 2013, 139:887-896.

56. Comen E, Balistreri L, Gönen M, Dutra-Clarke A, Fazio M, Vijai J, Stadler Z, Kauff N, Kirchhoff T, Hudis C, Offit K, Robson M: Discriminatory accuracy and potential clinical utility of genomic profiling for breast cancer risk in BRCA-negative women. Breast Cancer Res Treat 2011, 127:479-487.

57. Brentnall AR, Evans DG, Cuzick J: Distribution of breast cancer risk from SNPs and classical risk factors in women of routine screening age in the UK. Br J Cancer 2014, 110:827-828.

58. Evans DG, Warwick J, Astley SM, Stavrinos P, Sahin S, Ingham S, McBurney H, Eckersley B, Harvie M, Wilson M, Beetles U, Warren R, Hufton A, Sergeant JC, Newman WG, Buchan I, Cuzick J, Howell A: Assessing individual breast cancer risk within the U.K. National Health Service Breast Screening Program: a new paradigm for cancer prevention. Cancer Prev Res (Phila) 2012, 5:943-951.

59. Stacey SN, Manolescu A, Sulem P, Thorlacius S, Gudjonsson SA, Jonsson GF, Jakobsdottir M, Bergthorsson JT, Gudmundsson J, Aben KK, Strobbe LJ, 
Swinkels DW, van Engelenburg KC, Henderson BE, Kolonel LN, Le Marchand L, Millastre E, Andres R, Saez B, Lambea J, Godino J, Polo E, Tres A, Picelli S, Rantala J, Margolin S, Jonsson T, Sigurdsson H, Jonsdottir T, Hrafnkelsson J, et al: Common variants on chromosome $5 \mathrm{p} 12$ confer susceptibility to estrogen receptor-positive breast cancer. Nat Genet 2008, 40:703-706.

60. Garcia-Closas M, Couch FJ, Lindstrom S, Michailidou K, Schmidt MK, Brook MN, Orr N, Rhie SK, Riboli E, Feigelson HS, Le Marchand L, Buring JE, Eccles D, Miron P, Fasching PA, Brauch H, Chang-Claude J, Carpenter J, Godwin AK, Nevanlinna H, Giles GG, Cox A, Hopper JL, Bolla MK, Wang Q, Dennis J, Dicks E, Howat WJ, Schoof N, Bojesen SE, et al: Genome-wide association studies identify four ER negative-specific breast cancer risk loci. Nat Genet 2013, 45:392-398.

61. Purrington KS, Slettedahl S, Bolla MK, Michailidou K, Czene K, Nevanlinna H, Bojesen SE, Andrulis IL, Cox A, Hall P, Carpenter J, Yannoukakos D, Haiman CA, Fasching PA, Mannermaa A, Winqvist R, Brenner H, Lindblom A, Chenevix-Trench G, Benitez J, Swerdlow A, Kristensen V, Guénel P, Meindl A, Darabi H, Eriksson M, Fagerholm R, Aittomäki K, Blomqvist C, Nordestgaard BG, et al: Genetic variation in mitotic regulatory pathway genes is associated with breast tumor grade. Hum Mol Genet 2014. [Epub ahead of print].

62. Purrington $\mathrm{KS}$, Slager $\mathrm{S}$, Eccles $\mathrm{D}$, Yannoukakos D, Fasching PA, Miron $\mathrm{P}$, Carpenter J, Chang-Claude J, Martin NG, Montgomery GW, Kristensen V, Anton-Culver H, Goodfellow P, Tapper WJ, Rafiq S, Gerty SM, Durcan L, Konstantopoulou I, Fostira F, Vratimos A, Apostolou P, Konstanta I, Kotoula V, Lakis S, Dimopoulos MA, Skarlos D, Pectasides D, Fountzilas G, Beckmann MW, Hein A, et al: Genome-wide association study identifies 25 known breast cancer susceptibility loci as risk factors for triple-negative breast cancer. Carcinogenesis 2014, 35:1012-1019.

63. Garcia-Closas M, Burak Gunsoy N, Chatterjee N: Combined effects of genetic and environmental risk factors: implications for prevention of breast cancer. J Natl Cancer Inst. in press.

64. Key TJ, Appleby PN, Reeves GK, Roddam A, Dorgan JF, Longcope C, Stanczyk FZ, Stephenson HE Jr, Falk RT, Miller R, Schatzkin A, Allen DS, Fentiman IS, Key TJ, Wang DY, Dowsett M, Thomas HV, Hankinson SE, Toniolo P, Akhmedkhanov A, Koenig K, Shore RE, Zeleniuch-Jacquotte A, Berrino F, Muti P, Micheli A, Krogh V, Sieri S, Pala V, et al: Body mass index, serum sex hormones, and breast cancer risk in post-menopausal women J Natl Cancer Inst 2003, 95:1218-1226.

65. Hormones E, Group BCC, Key TJ, Appleby PN, Reeves GK, Travis RC, Alberg AJ, Barricarte A, Berrino F, Krogh V, Sieri S, Brinton LA, Dorgan JF, Dossus L, Dowsett M, Eliassen AH, Fortner RT, Hankinson SE, Helzlsouer KJ, Hoffman-Bolton J, Comstock GW, Kaaks R, Kahle LL, Muti P, Overvad K, Peeters PH, Riboli E, Rinaldi S, Rollison DE, Stanczyk FZ, et al: Sex hormones and risk of breast cancer in premenopausal women: a collaborative reanalysis of individual participant data from seven prospective studies. Lancet Oncol 2013, 14:1009-1019.

66. James RE, Lukanova A, Dossus L, Becker S, Rinaldi S, Tjønneland A, Olsen A Overvad K, Mesrine S, Engel P, Clavel-Chapelon F, Chang-Claude J, Vrieling A, Boeing H, Schütze M, Trichopoulou A, Lagiou P, Trichopoulos D, Palli D, Krogh V, Panico S, Tumino R, Sacerdote C, Rodríguez L, Buckland G, Sánchez MJ, Amiano P, Ardanaz E, Bueno-de-Mesquita B, Ros MM, et al: Post-menopausal serum sex steroids and risk of hormone receptor-positive and -negative breast cancer: a nested case-control study. Cancer Prev Res (Phila) 2011, 4:1626-1635.

67. Kaaks R, Tikk K, Sookthai D, Schock H, Johnson T, Tjønneland A, Olsen A, Overvad K, Clavel-Chapelon F, Dossus L, Baglietto L, Rinaldi S, Chajes V, Romieu I, Boeing H, Schütze M, Trichopoulou A, Lagiou P, Trichopoulos D, Palli D, Sieri S, Tumino R, Ricceri F, Mattiello A, Buckland G, Ramón Quirós J, Sánchez MJ, Amiano P, Chirlaque MD, Barricarte A, et al: Premenopausal serum sex hormone levels in relation to breast cancer risk, overall and by hormone receptor status - results from the EPIC cohort. Int I Cancer 2014, 134:1947-1957.

68. Ritte R, Lukanova A, Berrino F, Dossus L, Tjønneland A, Olsen A, Overvad TF, Overvad K, Clavel-Chapelon F, Fournier A, Fagherazzi G, Rohrmann S, Teucher B, Boeing H, Aleksandrova K, Trichopoulou A, Lagiou P, Trichopoulos D, Palli D, Sieri S, Panico S, Tumino R, Vineis P, Quirós JR, Buckland G, Sánchez MJ, Amiano P, Chirlaque MD, Ardanaz E, Sund M, et al: Adiposity, hormone replacement therapy use and breast cancer risk by age and hormone receptor status: a large prospective cohort study. Breast Cancer Res 2012, 14:R76.

69. Jones ME, Schoemaker MJ, Rae M, Folkerd EJ, Dowsett M, Ashworth A, Swerdlow AJ: Reproducibility of estradiol and testosterone levels in post-menopausal women over 5 years: results from the Breakthrough Generations Study. Am J Epidemiol 2014, 179:1128-1133.

70. Jones ME, Schoemaker M, Rae M, Folkerd E, Dowsett M, Ashworth A, Swerdlow $\mathrm{AJ}$ : Changes in estradiol and testosterone levels in post-menopausal women after changes in body mass index. J Clin Endocrinol Metab 2013, 98:2967-2974.

71. Tworoger SS, Zhang X, Eliassen AH, Qian J, Colditz GA, Willett WC, Rosner BA, Kraft P, Hankinson SE: Inclusion of endogenous hormone levels in risk prediction models of post-menopausal breast cancer. J Clin Oncol 2014. [Epub ahead of print].

72. Endogenous Hormones, Breast Cancer Collaborative Group: Insulin-like growth factor 1 (IGF1), IGF binding protein 3 (IGFBP3), and breast cancer risk: pooled individual data analysis of 17 prospective studies. Lancet Oncol 2010, 11:530-542.

73. Tworoger SS, Eliassen AH, Zhang X, Qian J, Sluss PM, Rosner BA, Hankinson SE: A 20-year prospective study of plasma prolactin as a risk marker of breast cancer development. Cancer Res 2013, 73:4810-4819.

74. Tikk K, Sookthai D, Johnson T, Rinaldi S, Romieu I, Tjønneland A, Olsen A, Overvad K, Clavel-Chapelon F, Baglietto L, Boeing H, Trichopoulou A, Lagiou P, Trichopoulos D, Palli D, Pala V, Tumino R, Rosso S, Panico S, Agudo A, Menéndez V, Sánchez MJ, Amiano P, Huerta Castaño JM, Ardanaz E, Bueno-de-Mesquita HB, Monninkhof E, Onland-Moret C, Andersson A, Sund $M$, et al: Circulating prolactin and breast cancer risk among pre- and post-menopausal women in the EPIC cohort. Ann Oncol 2014, 25:1422-1428.

75. Kaaks R, Johnson T, Tikk K, Sookthai D, Tjønneland A, Roswall N, Overvad K, Clavel-Chapelon F, Boutron-Ruault MC, Dossus L, Rinaldi S, Romieu I, Boeing H, Schütze M, Trichopoulou A, Lagiou P, Trichopoulos D, Palli D, Grioni S, Tumino R, Sacerdote C, Panico S, Buckland G, Argüelles M, Sánchez MJ, Amiano P, Chirlaque MD, Ardanaz E, Bueno-de-Mesquita HB, van Gils $\mathrm{CH}$, et al: Insulin-like growth factor I and risk of breast cancer by age and hormone receptor status - a prospective study within the EPIC cohort. Int J Cancer 2014, 134:2683-2690

76. Macdonald IK, Allen J, Murray A, Parsy-Kowalska CB, Healey GF, Chapman CJ, Sewell HF, Robertson JF: Development and validation of a high throughput system for discovery of antigens for autoantibody detection. PLoS One 2012, 7:e40759.

77. Sharma P, Sahni NS, Tibshirani R, Skaane $P$, Urdal $P$, Berghagen $H$, Jensen $M$, Kristiansen L, Moen C, Sharma P, Zaka A, Arnes J, Sauer T, Akslen LA Schlichting E, Børresen-Dale AL, Lönneborg A: Early detection of breast cancer based on gene-expression patterns in peripheral blood cells. Breast Cancer Res 2005, 7:R634-R644.

78. Almouzni G, Altucci L, Amati B, Ashley N, Baulcombe D, Beaujean N, Bock C, Bongcam-Rudloff E, Bousquet J, Braun S, Paillerets BB, Bussemakers M, Clarke L, Conesa A, Estivill X, Fazeli A, Grgurević N, Gut I, Heijmans BT, Hermouet S, Houwing-Duistermaat J, lacobucci I, Ilaš J, Kandimalla R, Krauss-Etschmann S, Lasko P, Lehmann S, Lindroth A, Majdič G, Marcotte E, et al: Relationship between genome and epigenome - challenges and requirements for future research. BMC Genomics 2014, 15:487.

79. Anderson KS, Sibani S, Wallstrom G, Qiu J, Mendoza EA, Raphael J, Hainsworth E, Montor WR, Wong J, Park JG, Lokko N, Logvinenko T, Ramachandran N, Godwin AK, Marks J, Engstrom P, Labaer J: Protein microarray signature of autoantibody biomarkers for the early detection of breast cancer. J Proteome Res 2011, 10:85-96.

80. Balbo S, Turesky RJ, Villalta PW: DNA adductomics. Chem Res Toxicol 2014 27:356-366

81. Advani $\mathrm{P}$, Moreno-Aspitia A: Current strategies for the prevention of breast cancer. Breast Cancer (Dove Med Press) 2014, 6:59-71

82. Chlebowski RT: Current concepts in breast cancer chemoprevention Pol Arch Med Wewn 2014, 124:191-199.

83. den Hollander P, Savage MI, Brown PH: Targeted therapy for breast cancer prevention. Front Oncol 2013, 3:250.

84. Steward WP, Brown K: Cancer chemoprevention: a rapidly evolving field. Br J Cancer 2013, 109:1-7.

85. Colditz GA, Bohlke K, Berkey CS: Breast cancer risk accumulation starts early: prevention must also. Breast Cancer Res Treat 2014, 145:567-579.

86. Harvie M, Howell A: Energy restriction and the prevention of breast cancer. Proc Nutr Soc 2012, 71:263-275.

87. Vogel VG, Costantino JP, Wickerham DL, Cronin WM, Cecchini RS, Atkins JN Bevers TB, Fehrenbacher L, Pajon ER, Wade JL 3rd, Robidoux A, Margolese RG, James J, Runowicz CD, Ganz PA, Reis SE, McCaskill-Stevens W, Ford LG, Jordan VC, Wolmark N: National Surgical Adjuvant Breast and Bowel 
Project: Update of the National Surgical Adjuvant Breast and Bowel Project Study of Tamoxifen and Raloxifene (STAR) P-2 Trial: preventing breast cancer. Cancer Prev Res (Phila) 2010, 3:696-706.

88. Manson JE, Chlebowski RT, Stefanick ML, Aragaki AK, Rossouw JE, Prentice RL, Anderson G, Howard BV, Thomson CA, LaCroix AZ, Wactawski-Wende J, Jackson RD, Limacher M, Margolis KL, Wassertheil-Smoller S, Beresford SA, Cauley JA, Eaton CB, Gass M, Hsia J, Johnson KC, Kooperberg C, Kuller LH, Lewis CE, Liu S, Martin LW, Ockene JK, O'Sullivan MJ, Powell LH, Simon MS, et al: Menopausal hormone therapy and health outcomes during the intervention and extended poststopping phases of the Women's Health Initiative randomized trials. JAMA 2013, 310:1353-1368.

89. Roth JA, Etzioni R, Waters TM, Pettinger M, Rossouw JE, Anderson GL, Chlebowski RT, Manson JE, Hlatky M, Johnson KC, Ramsey SD: Economic return from the Women's Health Initiative estrogen plus progestin clinical trial: a modeling study. Ann Intern Med 2014, 160:594-602.

90. Anderson GL, Chlebowski RT, Aragaki AK, Kuller LH, Manson JE, Gass M, Bluhm E, Connelly S, Hubbell FA, Lane D, Martin L, Ockene J, Rohan T, Schenken R, Wactawski-Wende J: Conjugated equine oestrogen and breast cancer incidence and mortality in post-menopausal women with hysterectomy: extended follow-up of the Women's Health Initiative randomised placebo-controlled trial. Lancet Oncol 2012, 13:476-486.

91. Howell A, Cuzick J: Oestrogen and breast cancer: results from the WHI trial. Lancet Oncol 2012, 13:437-438.

92. World Cancer Research Fund International: Cancer preventability estimates for food, nutrition, body fatness, and physical activity. http://www.wcrf.org/ cancer_statistics/preventability_estimates/preventability_estimates_food.php.

93. Renehan AG, Tyson M, Egger M, Heller RF, Zwahlen M: Body-mass index and incidence of cancer: a systematic review and meta-analysis of prospective observational studies. Lancet 2008, 371:569-578.

94. Harvie M, Howell A, Vierkant RA, Kumar N, Cerhan JR, Kelemen LE, Folsom AR, Sellers TA: Association of gain and loss of weight before and after menopause with risk of post-menopausal breast cancer in the lowa women's health study. Cancer Epidemiol Biomarkers Prev 2005 14:656-661.

95. Eliassen AH, Colditz GA, Rosner B, Willett WC, Hankinson SE: Adult weight change and risk of post-menopausal breast cancer. JAMA 2006, 296:193-201.

96. Cecchini RS, Costantino JP, Cauley JA, Cronin WM, Wickerham DL, Land SR, Weissfeld $J$, Wolmark N: Body mass index and the risk for developing invasive breast cancer among high-risk women in NSABP P-1 and STAR breast cancer prevention trials. Cancer Prev Res (Phila) 2012, 5:583-592.

97. Lindström J, llanne-Parikka P, Peltonen M, Aunola S, Eriksson JG, Hemiö K, Hämäläinen $H$, Härkönen P, Keinänen-Kiukaanniemi S, Laakso M, Louheranta A, Mannelin M, Paturi M, Sundvall J, Valle T, Uusitupa M, Tuomilehto Finnish Diabetes Prevention Study Group: Sustained reduction in the incidence of type 2 diabetes by lifestyle intervention: follow-up of the Finnish Diabetes Prevention Study. Lancet 2006, 368:1673-1679.

98. Diabetes Prevention Program Research Group, Knowler WC, Fowler SE, Hamman RF, Christophi CA, Hoffman HJ, Brenneman AT, Brown-Friday JO, Goldberg R, Venditti E, Nathan DM: 10-year follow-up of diabetes incidence and weight loss in the Diabetes Prevention Program Outcomes Study. Lancet 2009, 374:1677-1686

99. Ebrahim S, Taylor F, Ward K, Beswick A, Burke M, Davey Smith G: Multiple risk factor interventions for primary prevention of coronary heart disease. Cochrane Database Syst Rev 2011, 1:CD001561.

100. Van Gaal LF, Mertens IL, Ballaux D: What is the relationship between risk factor reduction and degree of weight loss? Eur Heart J Supp/ 2005, 7:L21-L26.

101. Prentice RL, Caan B, Chlebowski RT, Patterson R, Kuller LH, Ockene JK, Margolis KL, Limacher MC, Manson JE, Parker LM, Paskett E, Phillips L, Robbins J, Rossouw JE, Sarto GE, Shikany JM, Stefanick ML, Thomson CA, Van Horn L, Vitolins MZ, Wactawski-Wende J, Wallace RB, Wassertheil-Smoller S, Whitlock E, Yano K, Adams-Campbell L, Anderson GL, Assaf AR, Beresford SA, Black HR, et al: Low-fat dietary pattern and risk of invasive breast cancer: the Women's Health Initiative Randomized Controlled Dietary Modification Trial. JAMA 2006, 295:629-642.

102. Chlebowski RT, Blackburn GL, Thomson CA, Nixon DW, Shapiro A, Hoy MK, Goodman MT, Giuliano AE, Karanja N, McAndrew P, Hudis C, Butler J, Merkel D, Kristal A, Caan B, Michaelson R, Vinciguerra V, Del Prete S, Winkler M, Hall $R$, Simon $M$, Winters BL, Elashoff RM: Dietary fat reduction and breast cancer outcome: interim efficacy results from the Women's Intervention Nutrition Study. J Natl Cancer Inst 2006, 98:1767-1776.

103. Pierce JP, Natarajan L, Caan BJ, Parker BA, Greenberg ER, Flatt SW, Rock CL, Kealey S, Al-Delaimy WK, Bardwell WA, Carlson RW, Emond JA, Faerber S, Gold EB, Hajek RA, Hollenbach K, Jones LA, Karanja N, Madlensky L, Marshall J, Newman VA, Ritenbaugh C, Thomson CA, Wasserman L, Stefanick ML: Influence of a diet very high in vegetables, fruit, and fiber and low in fat on prognosis following treatment for breast cancer: the Women's Healthy Eating and Living (WHEL) randomized trial. JAMA 2007, 298:289-298.

104. Jung S, Spiegelman D, Baglietto L, Bernstein L, Boggs DA, van den Brandt PA, Buring JE, Cerhan JR, Gaudet MM, Giles GG, Goodman G, Hakansson N Hankinson SE, Helzlsouer K, Horn-Ross PL, Inoue M, Krogh V, Lof M, McCullough ML, Miller AB, Neuhouser ML, Palmer JR, Park Y, Robien K, Rohan TE, Scarmo S, Schairer C, Schouten LJ, Shikany JM, Sieri S, et al: Fruit and vegetable intake and risk of breast cancer by hormone receptor status. J Natl Cancer Inst 2013, 105:219-236.

105. Eliassen AH, Hendrickson SJ, Brinton LA, Buring JE, Campos H, Dai Q, Dorgan JF, Franke AA, Gao YT, Goodman MT, Hallmans G, Helzlsouer KJ, Hoffman-Bolton J, Hultén K, Sesso HD, Sowell AL, Tamimi RM, Toniolo P, Wilkens LR, Winkvist A, Zeleniuch-Jacquotte A, Zheng W, Hankinson SE: Circulating carotenoids and risk of breast cancer: pooled analysis of eight prospective studies. J Natl Cancer Inst 2012, 104:1905-1916.

106. Catsburg C, Miller AB, Rohan TE: Adherence to cancer prevention guidelines and risk of breast cancer. Int J Cancer 2014. [Epub ahead of print].

107. Thomson CA, McCullough ML, Wertheim BC, Chlebowski RT, Martinez ME, Stefanick ML, Rohan TE, Manson JE, Tindle HA, Ockene J, Vitolins MZ, Wactawski-Wende J, Sarto GE, Lane DS, Neuhouser ML: Nutrition and physical activity cancer prevention guidelines, cancer risk, and mortality in the women's health initiative. Cancer Prev Res (Phila) 2014, 7:42-53.

108. Link LB, Canchola AJ, Bernstein L, Clarke CA, Stram DO, Ursin G, Horn-Ross $\mathrm{PL}$ : Dietary patterns and breast cancer risk in the California Teachers Study cohort. Am J Clin Nutr 2013, 98:1524-1532.

109. Albuquerque RC, Baltar VT, Marchioni DM: Breast cancer and dietary patterns: a systematic review. Nutr Rev 2014, 72:1-17.

110. Ferrari $P$, Rinaldi S, Jenab M, Lukanova A, Olsen A, Tjønneland A, Overvad K, Clavel-Chapelon F, Fagherazzi G, Touillaud M, Kaaks R, von Rüsten A, Boeing H, Trichopoulou A, Lagiou P, Benetou V, Grioni S, Panico S, Masala G, Tumino R, Polidoro S, Bakker MF, van Gils CH, Ros MM, Bueno-de-Mesquita HB, Krum-Hansen S, Engeset D, Skeie G, Pilar A, Sánchez MJ, et al: Dietary fiber intake and risk of hormonal receptor-defined breast cancer in the European Prospective Investigation into Cancer and Nutrition study. Am J Clin Nutr 2013, 97:344-353.

111. Deschasaux M, Zelek L, Pouchieu C, His M, Hercberg S, Galan P, Latino-Martel $P$, Touvier M: Prospective association between dietary fiber intake and breast cancer risk. PLoS One 2013, 8:e79718.

112. Aune D, Chan DS, Vieira AR, Rosenblatt DA, Vieira R, Greenwood DC, Norat $\mathrm{T}$ : Fruits, vegetables and breast cancer risk: a systematic review and meta-analysis of prospective studies. Breast Cancer Res Treat 2012, 134:479-493.

113. Aune D, Chan DS, Vieira AR, Navarro Rosenblatt DA, Vieira R, Greenwood DC, Norat T: Dietary compared with blood concentrations of carotenoids and breast cancer risk: a systematic review and meta-analysis of prospective studies. Am J Clin Nutr 2012, 96:356-373.

114. Fung TT, Chiuve SE, Willett WC, Hankinson SE, Hu FB, Holmes MD: Intake of specific fruits and vegetables in relation to risk of estrogen receptor-negative breast cancer among post-menopausal women. Breast Cancer Res Treat 2013, 138:925-930.

115. Health and Social Care Information Centre: Health Survey for England (2102). http://www.hscic.gov.uk/catalogue/PUB13218.

116. Hastert TA, Beresford SA, Patterson RE, Kristal AR, White E: Adherence to WCRF/AICR cancer prevention recommendations and risk of post-menopausal breast cancer. Cancer Epidemiol Biomarkers Prev 2013, 22:1498-1508

117. Wiseman M: The second World Cancer Research Fund/American Institute for Cancer Research expert report. Food, nutrition, physical activity, and the prevention of cancer: a global perspective. Proc Nutr Soc 2008, 67:253-256.

118. Lynch BM, Neilson HK, Friedenreich CM: Physical activity and breast cancer prevention. Recent Results Cancer Res 2011, 186:13-42. 
119. Chen WY, Rosner B, Hankinson SE, Colditz GA, Willett WC: Moderate alcohol consumption during adult life, drinking patterns, and breast cancer risk. JAMA 2011, 306:1884-1890.

120. Zhang SM, Hankinson SE, Hunter DJ, Giovannucci EL, Colditz GA, Willett WC: Folate intake and risk of breast cancer characterized by hormone receptor status. Cancer Epidemiol Biomarkers Prev 2005, 14:2004-2008.

121. Ferrari $P$, Licaj I, Muller DC, Kragh Andersen $P$, Johansson M, Boeing $H_{\text {, }}$ Weiderpass E, Dossus L, Dartois L, Fagherazzi G, Bradbury KE, Khaw KT, Wareham N, Duell EJ, Barricarte A, Molina-Montes E, Sanchez CN, Arriola L, Wallström P, Tiønneland A, Olsen A, Trichopoulou A, Benetou V, Trichopoulos D, Tumino R, Agnoli C, Sacerdote C, Palli D, Li K, Kaaks R, et al: Lifetime alcohol use and overall and cause-specific mortality in the European Prospective Investigation into Cancer and nutrition (EPIC) study. BMJ Open 2014, 4:e005245.

122. Pike MC, Krailo MD, Henderson BE, Casagrande JT, Hoel DG: 'Hormonal' risk factors, 'breast tissue age' and the age-incidence of breast cancer. Nature 1983, 303:767-770.

123. Colditz GA, Frazier AL: Models of breast cancer show that risk is set by events of early life: prevention efforts must shift focus. Cancer Epidemiol Biomarkers Prev 1995, 4:567-571.

124. Liu Y, Colditz GA, Rosner B, Berkey CS, Collins LC, Schnitt SJ, Connolly JL, Chen WY, Willett WC, Tamimi RM: Alcohol intake between menarche and first pregnancy: a prospective study of breast cancer risk. J Natl Cancer Inst 2013, 105:1571-1578.

125. McNally S, Martin F: Molecular regulators of pubertal mammary gland development. Ann Med 2011, 43:212-234

126. Gjorevski N, Nelson CM: Integrated morphodynamic signalling of the mammary gland. Nat Rev Mol Cell Biol 2011, 12:581-593.

127. Cuzick J, Warwick J, Pinney E, Duffy SW, Cawthorn S, Howell A, Forbes JF, Warren RM: Tamoxifen-induced reduction in mammographic density and breast cancer risk reduction: a nested case-control study. J Nat/ Cancer Inst 2011, 103:744-752

128. Komm BS, Mirkin S: An overview of current and emerging SERMs. J Steroid Biochem Mol Biol 2014, 143:207-222

129. Johansson H, Bonanni B, Gandini S, Guerrieri-Gonzaga A, Cazzaniga M, Serrano D, Macis D, Puccio A, Sandri MT, Gulisano M, Formelli F, Decensi A: Circulating hormones and breast cancer risk in premenopausal women: a randomized trial of low-dose tamoxifen and fenretinide. Breast Cancer Res Treat 2013, 142:569-578.

130. Clarke RB, Howell A, Potten CS, Anderson E: Dissociation between steroid receptor expression and cell proliferation in the human breast. Cancer Res 1997, 57:4987-4991.

131. Brisken C, O'Malley B: Hormone action in the mammary gland. Cold Spring Harb Perspect Biol 2010, 2:a003178.

132. Shinomiya I, Marlow R, Buchupalli B, Gazinska P, Brown J, Catchpole S, Liu S, Barkan A, Wicha M, Purushotham A, Burchell J, Pinder S, Dontu G: Growth hormone is secreted by normal breast epithelium upon progesterone stimulation and increases proliferation of stem/progenitor cells. Stem Cell Reports 2014, 2:780-793.

133. Meier-Abt F, Bentires-Alj M: How pregnancy at early age protects against breast cancer. Trends Mol Med 2014, 20:143-153.

134. Chabbert-Buffet N, Meduri G, Bouchard P, Spitz IM: Selective progesterone receptor modulators and progesterone antagonists: mechanisms of action and clinical applications. Hum Reprod Update 2005, 11:293-307.

135. Harvard Medical School: Growing up today study. http://www.gutsweb.org.

136. Baer HJ, Tworoger SS, Hankinson SE, Willett WC: Body fatness at young ages and risk of breast cancer throughout life. Am J Epidemiol 2010, 171:1183-1194.

137. Hilakivi-Clarke L, Forsén T, Eriksson JG, Luoto R, Tuomilehto J, Osmond C, Barker DJ: Tallness and overweight during childhood have opposing effects on breast cancer risk. Br J Cancer 2001, 85:1680-1684.

138. Robinson WR, Tse CK, Olshan AF, Troester MA: Body size across the life course and risk of premenopausal and post-menopausal breast cancer in Black women, the Carolina Breast Cancer Study, 1993-2001. Cancer Causes Control 2014, 25:1101-1117.

139. Suzuki R, Iwasaki M, Inoue M, Sasazuki S, Sawada N, Yamaji T, Shimazu T, Tsugane S: Body weight at age 20 years, subsequent weight change and breast cancer risk defined by estrogen and progesterone receptor status - the Japan public health center-based prospective study. Int J Cancer 2011, 129:1214-1224.
140. Barnes-Josiah D, Potter JD, Sellers TA, Himes JH: Early body size and subsequent weight gain as predictors of breast cancer incidence (lowa, United States). Cancer Causes Control 1995, 6:112-118.

141. Feigelson HS, Jonas CR, Teras LR, Thun MJ, Calle EE: Weight gain, body mass index, hormone replacement therapy, and post-menopausal breast cancer in a large prospective study. Cancer Epidemiol Biomarkers Prev 2004, 13:220-224.

142. Krishnan K, Bassett JK, Maclnnis RJ, English DR, Hopper JL, McLean C, Giles GG, Baglietto L: Associations between weight in early adulthood, change in weight, and breast cancer risk in post-menopausal women. Cancer Epidemiol Biomarkers Prev 2013, 22:1409-1416.

143. Magnusson CM, Roddam AW: Breast cancer and childhood anthropometry: emerging hypotheses? Breast Cancer Res 2005, 7:83.

144. Poole EM, Tworoger SS, Hankinson SE, Schernhammer ES, Pollak MN, Baer $\mathrm{HJ}$ : Body size in early life and adult levels of insulin-like growth factor 1 and insulin-like growth factor binding protein 3. Am J Epidemiol 2011, 174:642-651.

145. Michels KB, Terry KL, Eliassen AH, Hankinson SE, Willett WC: Adult weight change and incidence of premenopausal breast cancer. Int J Cancer 2012, 130:902-909.

146. De Stavola BL, dos Santos SI, McCormack V, Hardy RJ, Kuh DJ, Wadsworth ME: Childhood growth and breast cancer. Am J Epidemiol 2004, 159:671-682.

147. Berkey CS, Willett WC, Frazier AL, Rosner B, Tamimi RM, Rockett HR, Colditz $\mathrm{GA}$ : Prospective study of growth and development in older girls and risk of benign breast disease in young women. Cancer 2011, 117:1612-1620.

148. Cheng G, Buyken AE, Shi L, Karaolis-Danckert N, Kroke A, Wudy SA, Degen $\mathrm{GH}$, Remer T: Beyond overweight: nutrition as an important lifestyle factor influencing timing of puberty. Nutr Rev 2012, 70:133-152.

149. Lyons TR, O'Brien J, Borges VF, Conklin MW, Keely PJ, Eliceiri KW, Marusyk A, Tan AC, Schedin P: Postpartum mammary gland involution drives progression of ductal carcinoma in situ through collagen and COX-2. Nat Med 2011, 17:1109-1115.

150. Bartow SA, Pathak DR, Black WC, Key CR, Teaf SR: Prevalence of benign, atypical, and malignant breast lesions in populations at different risk for breast cancer. A forensic autopsy study. Cancer 1987, 60:2751-2760.

151. Nielsen M, Thomsen JL, Primdahl S, Dyreborg U, Andersen JA: Breast cancer and atypia among young and middle-aged women: a study of 110 medicolegal autopsies. Br J Cancer 1987, 56:814-819.

152. Haricharan S, Dong J, Hein S, Reddy JP, Du Z, Toneff M, Holloway K, Hilsenbeck SG, Huang S, Atkinson R, Woodward W, Jindal S, Borges VF Gutierrez C, Zhang H, Schedin PJ, Osborne CK, Tweardy DJ, Li Y: Mechanism and preclinical prevention of increased breast cancer risk caused by pregnancy. Elife 2013, 2:e00996.

153. Britschgi A, Andraos R, Brinkhaus H, Klebba I, Romanet V, Müller U, Murakami M, Radimerski T, Bentires-Alj M: AK2/STAT5 inhibition circumvents resistance to $\mathrm{PI} 3 \mathrm{~K} / \mathrm{mTOR}$ blockade: a rationale for cotargeting these pathways in metastatic breast cancer. Cancer Cell 2012, 22:796-811.

154. Wellings SR, Jensen HM, Marcum RG: An atlas of subgross pathology of the human breast with special reference to possible precancerous lesions. J Natl Cancer Inst 1975, 55:231-273.

155. Milanese TR, Hartmann LC, Sellers TA, Frost MH, Vierkant RA, Maloney SD, Pankratz VS, Degnim AC, Vachon CM, Reynolds CA, Thompson RA, Melton $\mathrm{L}$ 3rd, Goode EL, Visscher DW: Age-related lobular involution and risk of breast cancer. J Natl Cancer Inst 2006, 98:1600-1607.

156. McKian KP, Reynolds CA, Visscher DW, Nassar A, Radisky DC, Vierkant RA, Degnim AC, Boughey JC, Ghosh K, Anderson SS, Minot D, Caudill JL, Vachon CM, Frost MH, Pankratz VS, Hartmann LC: Novel breast tissue feature strongly associated with risk of breast cancer. J Clin Oncol 2009, 27:5893-5898.

157. Allan DJ, Howell A, Roberts SA, Williams GT, Watson RJ, Coyne JD, Clarke RB, Laidlaw IJ, Potten CS: Reduction in apoptosis relative to mitosis in histologically normal epithelium accompanies fibrocystic change and carcinoma of the premenopausal human breast. J Pathol 1992, 167:25-32.

158. Deng J, Letai A: Priming BCL-2 to kill: the combination therapy of tamoxifen and ABT-199 in ER + breast cancer. Breast Cancer Res 2013, 15:317.

159. Kerlikowske K, Ichikawa L, Miglioretti DL, Buist DS, Vacek PM, Smith-Bindman R, Yankaskas B, Carney PA, Ballard-Barbash R: National Institutes of Health Breast Cancer Surveillance Consortium: Longitudinal measurement of clinical mammographic breast density to improve estimation of breast cancer risk. J Natl Cancer Inst 2007, 99:386-395. 
160. Work ME, Reimers LL, Quante AS, Crew KD, Whiffen A, Terry MB: Changes in mammographic density over time in breast cancer cases and women at high risk for breast cancer. Int J Cancer 2014, 135:1740-1744.

161. Hattar R, Maller O, McDaniel S, Hansen KC, Hedman KJ, Lyons TR, Lucia S, Wilson RS Jr, Schedin P: Tamoxifen induces pleiotrophic changes in mammary stroma resulting in extracellular matrix that suppresses transformed phenotypes. Breast Cancer Res 2009, 11:R5.

162. Lisanti MP, Tsirigos A, Pavlides S, Reeves KJ, Peiris-Pagès M, Chadwick AL, Sanchez-Alvarez R, Lamb R, Howell A, Martinez-Outschoorn UE, Sotgia F: JNK1 stress signaling is hyper-activated in high breast density and the tumor stroma: connecting fibrosis, inflammation, and stemness for cancer prevention. Cell Cycle 2014, 13:580-599.

163. Gross ND, Boyle JO, Du B, Kekatpure VD, Lantowski A, Thaler HT, Weksler BB, Subbaramaiah K, Dannenberg AJ: Inhibition of Jun NH2-terminal kinases suppresses the growth of experimental head and neck squamous cell carcinoma. Clin Cancer Res 2007, 13:5910-5917.

164. Dumont N, Liu B, Defilippis RA, Chang H, Rabban JT, Karnezis AN, Tjoe JA, Marx J, Parvin B, TIsty TD: Breast fibroblasts modulate early dissemination, tumorigenesis, and metastasis through alteration of extracellular matrix characteristics. Neoplasia 2013, 15:249-262.

165. Mattson MP, Allison DB, Fontana L, Harvie M, Longo VD, Malaisse W, Mosley M, Notterpek L, Ravussin E, Scheer F, Seyfried T, Varady K, Panda S: Meal frequency, timing and intermittent energy restriction in health and disease. $J$ Natl Cancer Inst. in press.

166. Arendt LM, McCready J, Keller PJ, Baker DD, Naber SP, Seewaldt V, Kuperwasser C Obesity promotes breast cancer by CCL2-mediated macrophage recruitment and angiogenesis. Cancer Res 2013, 73:6080-6093.

167. Howe LR, Subbaramaiah K, Hudis CA, Dannenberg AJ: Molecular pathways: adipose inflammation as a mediator of obesity-associated cancer. Clin Cancer Res 2013, 19:6074-6083.

168. Lashinger LM, Ford NA, Hursting SD: Interacting inflammatory and growth factor signals underlie the obesity-cancer link. J Nutr 2014, 144:109-113.

169. de Cabo R, Carmona-Gutierrez D, Bernier M, Hall MN, Madeo F: The search for antiaging interventions: from elixirs to fasting regimens. Cell 2014, 157:1515-1526.

170. Mercken EM, Mitchell SJ, Martin-Montalvo A, Minor RK, Almeida M, Gomes AP, Scheibye-Knudsen M, Palacios HH, Licata JJ, Zhang Y, Becker KG, Khraiwesh H, González-Reyes JA, Villalba JM, Baur JA, Elliott P, Westphal C, Vlasuk GP, Ellis JL, Sinclair DA, Bernier M, de Cabo R: SRT2104 extends survival of male mice on a standard diet and preserves bone and muscle mass. Aging Cell 2014. [Epub ahead of print].

171. Badrick E, Renehan AG: Diabetes and cancer: 5 years into the recent controversy. Eur J Cancer 2014, 50:2119-2125.

172. Goodwin PJ, Thompson AM, Stambolic V: Diabetes, metformin, and breast cancer: lilac time? J Clin Oncol 2012, 30:2812-2814.

173. Campbell KL, McTiernan A: Exercise and biomarkers for cancer prevention studies. J Nutr 2007, 137(1 Suppl):161S-169S.

174. Bernstein L: Exercise and breast cancer prevention. Curr Oncol Rep 2009, 11:490-496.

175. Wheatley KE, Nogueira LM, Perkins SN, Hursting SD: Differential effects of calorie restriction and exercise on the adipose transcriptome in diet-induced obese mice. J Obes 2011, 2011:265417.

176. Neilson HK, Conroy SM, Friedenreich CM: The influence of energetic factors on biomarkers of post-menopausal breast cancer risk. Curr Nutr Rep 2014, 3:22-34

177. Zeng H, Irwin ML, Lu L, Risch H, Mayne S, Mu L, Deng Q, Scarampi L, Mitidiera M, Katsaros D, Yu H: Physical activity and breast cancer survival: an epigenetic link through reduced methylation of a tumor suppressor gene L3MBTL1. Breast Cancer Res Treat 2012, 133:127-135.

178. Shammas MA: Telomeres, lifestyle, cancer, and aging. Curr Opin Clin Nutr Metab Care 2011, 14:28-34

179. Ludlow AT, Roth SM: Physical activity and telomere biology: exploring the link with aging-related disease prevention. J Aging Res 2011, 21:2011.

180. Visser M, Bouter LM, McQuillan GM, Wener MH, Harris TB: Elevated C-reactive protein levels in overweight and obese adults. JAMA 1999, 282:2131-2135.

181. Esposito K, Pontillo A, Di Palo C, Giugliano G, Masella M, Marfella R, Giugliano D: Effect of weight loss and lifestyle changes on vascular inflammatory markers in obese women: a randomized trial. JAMA 2003, 289:1799-1804.
182. Jung SH, Park HS, Kim KS, Choi WH, Ahn CW, Kim BT, Kim SM, Lee SY, Ahn SM, Kim YK, Kim HJ, Kim DJ, Lee KW: Effect of weight loss on some serum cytokines in human obesity: increase in IL-10 after weight loss. J Nutr Biochem 2008, 19:371-375.

183. Thompson HJ, Jiang W, Zhu Z: Candidate mechanisms accounting for effects of physical activity on breast carcinogenesis. IUBMB Life 2009, 61:895-901.

184. Strasser-Weippl K, Goss PE: Suitable trial designs and cohorts for preventive breast cancer agents. Nat Rev Clin Oncol 2013, 10:677-687.

185. Moyer VA, U.S. Preventive Services Task Force: Medications to decrease the risk for breast cancer in women: recommendations from the U.S. Preventive Services Task Force recommendation statement. Ann Intern Med 2013, 159:698-708.

186. Freedman AN, Yu B, Gail MH, Costantino JP, Graubard BI, Vogel VG, Anderson GL, McCaskill-Stevens W: Benefit/risk assessment for breast cancer chemoprevention with raloxifene or tamoxifen for women age 50 years or older. $J$ Clin Oncol 2011, 29:2327-2333.

187. Visvanathan K, Hurley P, Bantug E, Brown P, Col NF, Cuzick J, Davidson NE, Decensi A, Fabian C, Ford L, Garber J, Katapodi M, Kramer B, Morrow M, Parker B, Runowicz C, Vogel VG 3rd, Wade JL, Lippman SM: Use of pharmacologic interventions for breast cancer risk reduction: American Society of Clinical Oncology clinical practice guideline. J Clin Oncol 2013, 31:2942-2962.

188. Evans DG, Graham J, O'Connell S, Arnold S, Fitzsimmons D: Familial breast cancer: summary of updated NICE guidance. BMJ 2013, 346:f3829.

189. Kushi LH, Doyle C, McCullough M, Rock CL, Demark-Wahnefried W, Bandera EV, Gapstur S, Patel AV, Andrews K, Gansler T, Society AC: Nutrition and Physical Activity Guidelines Advisory Committee: American Cancer Society Guidelines on nutrition and physical activity for cancer prevention: reducing the risk of cancer with healthy food choices and physical activity. CA Cancer J Clin 2010, 2012(62):30-67.

190. Norat T, Aune D, Chan D, Romaguera D: Fruits and vegetables: updating the epidemiologic evidence for the WCRF/AICR lifestyle recommendations for cancer prevention. Cancer Treat Res 2014, 159:35-50.

191. Anderson AS, Mackison D, Boath C, Steele R: Promoting changes in diet and physical activity in breast and colorectal cancer screening settings: an unexplored opportunity for endorsing healthy behaviors. Cancer Prev Res (Phila) 2013, 6:165-172.

192. US Institute of Medicine: Accelerating Progress in Obesity Prevention: Solving the Weight of the Nation. http://www.iom.edu/ /media/Files/ Report\%20Files/2012/APOP/APOP_insert.pdf.

193. US Institute of Medicine: The Current State of Obesity Solutions in the United States - Workshop Summary. http://www.iom.edu/Reports/2014/ The-Current-State-of-Obesity-Solutions-in-the-United-States.aspx.

194. Colditz GA, Wolin KY, Gehlert S: Applying what we know to accelerate cancer prevention. Sci Transl Med 2012, 4:127rv4.

doi:10.1186/s13058-014-0446-2

Cite this article as: Howell et al:: Risk determination and prevention of breast cancer. Breast Cancer Research 2014 16:446. 